\title{
CONHECIMENTO E DECISÃO: A GESTÃO DO CONHECIMENTO PESSOAL PARA A TOMADA DE DECISÕES CORPORATIVAS
}

\section{KNOWLEDGE AND DECISION: THE PERSONAL KNOWLEDGE MANAGEMENT FOR ORGANIZATIONALS DECISIONS-MAKING}

\author{
Gilberto dos Santos Madeira ${ }^{1}$; Moacir Pereira ${ }^{2}$ \\ ${ }^{1}$ Fundação Getúlio Vargas - FGV - Rio de Janeiro- Brasil \\ gilmadeira@,fgvmail.br \\ ${ }^{2}$ Centro Universitário Salesiano de São Paulo - UNISAL - Americana - Brasil \\ pereira_moacir@yahoo.com.br
}

\begin{abstract}
Resumo
A economia globalizada, aliada à Tecnologia da Informação e da Comunicação, tem provocado mudanças revolucionárias em conceitos e valores, sejam eles sociais, culturais, econômicos, demográficos ou pessoais. Este trabalho é uma análise das contribuições teóricas, das práticas corporativas e dos arquétipos de Gestão do Conhecimento Pessoal, com o objetivo de estudar como essa gestão contribui para que o executivo tome decisões empresariais efetivas e assertivas, tendo por base os processos de gerenciamento do conhecimento tácito e explícito, e que agreguem valor aos executivos nos momentos de tomada de decisão corporativa, pois, presume-se que a existência de Gestão do Conhecimento Pessoal e Organizacional, propiciará aos executivos, fazerem um melhor uso das informações disponíveis, adquirindo clareza e reduzindo ambiguidades dos dados coletados.
\end{abstract}

Palavras-chave: gestão do conhecimento; processo decisório; aprendizagem organizacional.

\section{Introdução}

A velocidade com que as mudanças ocorrem no cenário mundial, em particular no mundo corporativo, diminui o impacto das atividades empresariais, e as faz perder suas características vanguardistas muito rapidamente.

Ao contrário do século XIX, que foi caracterizado por grandes convicções, o século XX foi marcado por abalos. A afirmativa do filósofo inglês Bertrand Russel (1977), bem expressa este conceito: “[...] no século XX, os fundamentos do mundo sofreram contínuos abalos. E a coisa mais penosa dessa época é que só os tolos exibem convicções e certezas, enquanto os que possuem imaginação e raciocínio vivem repletos de dúvidas e indecisões”.

A verdade atual é que o ambiente organizacional é dinâmico, e ter, por exemplo, disponibilidade de capital financeiro; uma marca mercadologicamente bem posicionada; a produção de bens ou serviços com tradição e reconhecimento pelo seu valor agregado ao cliente; capacidade 
de penetração em nichos de mercado; detenção de importante fatia do mercado consumidor; ou uma significante rede de canais de distribuição capaz de garantir fácil acesso dos compradores aos produtos, já não podem ser consideradas como vantagens competitivas com efeito de longa duração, na arena onde as disputas concorrenciais acontecem.

A visão da ciência econômica tradicional de base neoclássica, de empresas meramente baseadas em recursos entrantes e despendidos para satisfazer mercados dos quais participam, já não pode ser considerada estratégia determinante de sucesso. A dinâmica que estabelece diferenciais competitivos está na eficácia da apropriação do "[...] conhecimento subjacente das rotinas e práticas, que a empresa transforma em produtos e serviços valiosos” (Davenport, 1999).

Alinhar as estratégias organizacionais aos interesses dos stakeholders; garantir espaço de qualidade nas disputas com os concorrentes e, principalmente, tornar-se uma empresa que aprende com seus erros e acertos, é tarefa intrigante que desafia os gestores contemporâneos.

Há uma nova formulação, no âmbito do mundo corporativo, no qual a competição é cada vez mais acirrada. O embate já não acontece num contexto geograficamente restrito, mas se desenrola em esfera mundial, pois o espaço de disputa é planetário, em todas as dimensões: sociais, culturais, políticas, econômicas, religiosas e ideológicas. Essa globalização, que pode ser entendida como uma crescente interconexão nos fluxos de informação, tecnologia, capital, bens, serviços e indivíduos em todo o mundo, é uma força que poderá dar forma a todas as outras grandes megatendências, que irão caracterizar o século XXI.

A revolução provocada pela criação de novos espaços de mercado e pela busca do rompimento com a concorrência tem, na tecnologia da informação, provavelmente, o instrumento de maior significância na ampliação do alcance dos seus efeitos, especialmente na economia mundial. A tecnologia da informação, aliada aos impactos causados por transformações, abertura e liberalização de mercados, destruiu as fronteiras das relações comerciais entre os povos e aprofundou substancialmente a interdependência global.

Em Bauman (1998, 1999) é possível se compreender que esse mundo globalizado, a reboque de constantes mutações tecnológicas, experimenta um processo irreversível de quebra de modelos paradigmáticos, notadamente daqueles que se referem à compreensão de tempo e espaço. Essa dinâmica, certamente, encerra grandes e profundas transformações nas práticas e padrões profissionais, e no curso da condição humana. Contudo, ainda que traga benefícios, enriquecendo a maior parte do mundo, a globalização da economia, por outro lado, tem o seu lado perverso, sobre o qual não se tem por objetivo abordar neste artigo.

A arena competitiva tem obrigado as organizações a fazerem pesquisas e a produzirem informações que lhes permitam entender o seu ambiente de atuação, se adaptarem a ele, e criarem estratégias que lhes garantam a permanência na competição corporativa por novos mercados, novos 
clientes, maior lucratividade, maior rentabilidade, ou por inovações produzidas em seus quadros, com vistas a serem bem-sucedidas. Executivos, portanto, estão, constantemente, submetidos à pressão de decidir, e essa tomada de decisão demanda uma gama significativa de informações, que lhes reduza a ambiguidade das situações, e lhes deem a necessária clareza para uma tomada de decisão segura, efetiva e assertiva.

Em Nonaka e Takeuchi (2009), se encontra a fundamentação que justifica a importância acadêmica e empresarial, para se levar avante esta reflexão.

[...] A visão da organização como uma máquina para o "processamento de informações" está profundamente inserida na tradição administrativa ocidental, que vai de Frederick Taylor a Herbert Simon. De acordo com essa visão, o único conhecimento verdadeiramente útil é o formal e sistemático - dados difíceis (leia-se: quantificáveis), procedimentos codificados, princípios universais. $\mathrm{E}$ as métricas-chave para mensurar o valor do novo conhecimento são similarmente difíceis e quantificáveis - crescente eficiência, custos mais baixos, melhor retorno do investimento (ROI).

Mas existe outra forma de medir o conhecimento e seu papel nas organizações empresariais. Costuma ser encontrada nos concorrentes japoneses mais bem sucedidos, como Honda, Canon, Matsushita, NEC, Sharp e Kao. Essas empresas tornaram-se famosas por sua capacidade de responder rapidamente aos clientes, criar novos mercados, desenvolver agilmente novos produtos e dominar tecnologias emergentes. O segredo de seu sucesso é sua abordagem exclusiva da gestão da criação do novo conhecimento.

[...] O cerne da abordagem japonesa é o reconhecimento de que a criação do novo conhecimento não se refere simplesmente ao "processamento" da informação objetiva. Ao contrário, depende da exploração de insights tácitos e, com frequência, altamente subjetivos das intuições e dos palpites dos empregados individuais e de torná-los disponíveis para teste e uso pela empresa como um todo. A chave para esse processo é compromisso pessoal, a sensação de identidade dos empregados com o empreendimento e com sua missão.

\section{Objetivo}

Este é, então, um estudo sobre a criação, a disseminação e o uso do conhecimento pessoal, como fonte de desenvolvimento e construção das competências na organização, procurando envolver assuntos relacionados a tecnologias, dinâmica organizacional, modelos de gestão, cultura organizacional, estratégias, seus gerenciamentos e aprendizagem nas organizações.

Desta feita, analisa-se aqui, como a gestão do conhecimento pessoal contribui para que o executivo tome decisões empresariais efetivas e assertivas.

A suposição que se levanta é que relatórios gerenciais endógenos fornecem informações confiáveis para que o gestor consiga emanar suas decisões com o mínimo de certeza, dentro de um quadro geral e global de incertezas, bem como a utilização da sua experiência e do seu conhecimento tácito.

Vale ressaltar que a realidade brasileira ainda sinaliza um baixo grau de profissionalismo, o que implica em tomadas de decisões em cima dos tão conhecidos "achismos", praticados no âmbito corporativo. Essa prática recorrente e imprópria tem causado estragos, algumas vezes até irreversíveis, em empresas, onde executivos utilizam esse recurso em sua cultura gerencial. 
Buscando vislumbrar o contexto organizacional futuro, pensa-se que o diferencial que capacitará uma organização a ir além da sua permanência no mercado, somente poderá ser encontrado e adquirido, por meio da produção de soluções para esse contexto de empresas interrelacionadas e interconectadas, e do conhecimento gerado internamente, de maneira explícita, na forma de documentos, relatórios, memorandos, arquivos digitais, além da utilização do conhecimento tácito, que permeia as mentes de seus colaboradores, seja pelas experiências, seja pelas especialidades, ou pelo know-how inerente à vivência do processo de construção do conhecimento individual.

Contudo, acredita-se que apenas as organizações que atentam para a análise da sua estrutura de geração de conhecimento é que se qualificarão a se manter fortes diante dos concorrentes, no complexo e competitivo cenário empresarial que está posto. Será, seguramente, pela compreensão da qualidade da utilização do conhecimento gerado, pela mensuração dos benefícios que são produzidos por intermédio da sua sistematização, e da socialização desse conhecimento, que essas organizações produzirão habilidades únicas, capazes de atender às demandas da sociedade do conhecimento.

Nessa dinâmica, portanto, gestores têm que trabalhar a construção do conhecimento em duas perspectivas: endógena e exógena.

Na perspectiva endógena, no dizer de Choo (2006),

[...] a construção do conhecimento é conseguida quando se reconhece o relacionamento sinérgico entre o conhecimento tácito e o conhecimento explícito dentro de uma organização, e quando são elaborados processos sociais capazes de criar novos conhecimentos por meio da conversão do conhecimento tácito em conhecimento explícito.

A partir do ponto de vista exógeno, as interferências externas obrigam as empresas a aguçarem seus olhares sobre o ambiente exterior, a fim de que mudanças no meio organizacional se tornem perceptíveis, formem um mapa de variáveis, e promovam conexões com os ambientes interpretados.

Essa dinâmica implica, obrigatoriamente, na mudança de alguns paradigmas, dentre os quais, o da "certeza absoluta", que durante a modernidade consolidou as tomadas de decisões, mas que foi quebrado na pós-modernidade, quando a visão probabilística passou a vigir. Tal contexto, por sua vez, obriga os executivos a repensarem suas gestões administrativas e suas tomadas de decisões.

Sabe-se que modelos teoricamente concebidos servem de referenciais às suas ações. Entretanto, a avalanche de informações advindas dos ambientes endógenos, exógenos e do mundo virtual necessita de gerenciamento, para tomada de decisões assertivas. 


\section{Gestão do conhecimento pessoal}

Ao se proceder uma análise da sociedade ocidental dos dias atuais e suas perspectivas futuras, há de se compreender que os gestores são profissionais permanentemente pressionados para produzir, rapidamente, resultados elevados, porque o mundo busca respostas prontas, do tipo plug and play, embora aceitando até soluções simplórias e efêmeras, desde que deem respostas imediatas, ainda que descartáveis. Para atingir a velocidade demandada pela sociedade atual, na entrega de seus resultados, os gestores, obrigatoriamente, necessitam de uma vasta gama de conhecimentos que lhes permitirá desenvolver competências e habilidades, para tomarem decisões efetivas e assertivas.

Como, então, gerir a profusão de dados, informações e conhecimentos que têm sido produzido por essa sociedade pós-capitalista, onde, no dizer de Drucker (1999), o recurso econômico fundamental já não é a terra, a mão-de-obra ou o capital, mas o conhecimento?

A primeira década do século XXI, no entender de Drucker (1999) e Ariely (2009), evidencia a consolidação do processo de valoração do papel do conhecimento nos procedimentos e rotinas organizacionais, iniciado na segunda metade do século passado, visto que as megatendências corporativas, advindas do processo de globalização dos negócios, têm favorecido sobremaneira a substituição do uso da força física, pelo uso do conhecimento, na elaboração e execução de tarefas, o qual se destaca como um fator de produção que, por suas inúmeras razões, agrega grande valor à empresa, frente à velocidade a que o ciclo de vida de um negócio está sendo submetido.

Segundo Crossan, Lane e White (1999), o tema Gestão do Conhecimento (doravante tratada como GC), existe desde que Cangelosi e Dill (1965) discutiram o tópico. Após isso, a popularidade desse assunto cresceu significativamente, com novos autores convergindo, o que tem contribuído para a formação de um consenso, sobre o significado do termo.

De todo modo, o conceito, ou a busca do entendimento conceitual de GC evoluiu de forma mais acentuada, a partir do pensamento de acadêmicos e pioneiros no assunto, como Michael Polanyi nos idos de 1966, Peter Drucker e Chris Argyris na década de 70, Karl Erik Sveiby e Arie de Geus no final de 80, Nonaka e Takeuchi e Peter Senge nos anos 90, e Chun Wei Choo e Gilbert Probst no início do século XXI, para registrar alguns autores que fizeram diferença teóricoconceitual a respeito do assunto que aqui se aborda.

Durante esse tempo, as mudanças econômicas, sociais e tecnológicas foram transformando a maneira das empresas trabalharem. A globalização surgiu, e trouxe novas oportunidades, mas, aumentou a concorrência. Empresas responderam a esse acirramento concorrencial com downsizing, fusão, aquisição, reengenharia e terceirização. Muitas racionalizaram sua força de trabalho e aumentaram sua produtividade e lucros, utilizando-se dos avanços na computação e da 
tecnologia pertinente à Internet. No entanto, essas transformações trouxeram sucessos, em alguns casos, mas acarretaram custos elevados. Muitas, nesses processos de mudança e adaptação, perderam o conhecimento da empresa, e chegaram ao ponto de não mais saber o que sabiam e como faziam.

No início dos anos 90, um crescente grupo de acadêmicos e consultores voltou então, a falar sobre GC como "a nova prática" empresarial, e, cada vez mais, o assunto começou a despontar em revistas de negócios e nas agendas de conferências corporativas.

Em meados da década de 90, tornou-se amplamente reconhecido que significativas vantagens competitivas, de algumas das principais empresas do mundo estavam sendo esculpidas por meio de seus ativos intelectuais, tais como geração de competências, intensificação das relações com clientes e introdução de inovações. A GC, portanto, se tornou de repente a principal tendência de negócio, na tentativa, por parte das empresas menores, de seguir os líderes de mercado. Muitas dessas empresas, contudo, erraram na estratégia de implementação de soluções de GC, centrandose, quase que inteiramente, em tecnologias de GC, obtendo sucesso limitado, e assim, começaram a questionar se a GC não era apenas mais um modismo, que parecia ser uma ótima idéia no papel, mas que, na realidade, não se obteriam resultados significativos. No entanto, com o tempo os gestores perceberam que o problema não era o conceito de GC como tal, mas sim a maneira como este havia sido abordado e implantado.

Então, por GC, o que pode ser feito é estabelecer um ambiente no qual as pessoas que nele trabalham e os clientes dessa organização, sejam incentivados a, conjuntamente, criar, aprender, partilhar e utilizar os conhecimentos alcançados.

É mister que se faça um esclarecimento neste ponto do texto, com o objetivo de destacar que o caminho a ser trilhado ao se tratar de GC, será o organizacional - explícito, e o pessoal - tácito, os quais, em certos momentos, irão se confundir, ou, para melhor dizer, irão se entretecer mutuamente, especialmente quando, conjuntamente, estiverem em operação no habitat corporativo.

Faz-se essa ressalva, porque o conhecimento nas organizações, muitas vezes, é classificado em dois tipos: explícito e tácito.

Por conhecimento explícito se quer expor o conhecimento organizacional, codificado, transmissível em linguagem formal e sistemática. E o conhecimento tácito é pessoal, específico ao contexto e, assim, difícil de ser formulado e comunicado ${ }^{1}$.

Em termos organizacionais, o conhecimento é geralmente considerado como sendo knowhow, ou ações aplicadas a algo, pelo saber fazer. Em se tratando do conhecimento pessoal, não deixa de ser know-how, só que as ações apostas, por sua vez, não são, necessariamente, apenas no ecossistema profissional, mas, também, na própria vida.

\footnotetext{
${ }^{1}$ Para estas definições, lança-se mão dos pressupostos explicitados por Michael Polanyi (2009).
} 
Para Drucker (1999), o conhecimento representa, na organização, bem mais do que o capital ou o trabalho, por se tratar do único e significativo recurso econômico da sociedade pós-capitalista, e o papel preponderante do gestor é propiciar o contexto adequado à boa utilização e à boa performance do conhecimento, por meio da aplicação do conhecimento ao conhecimento.

O bom desempenho de uma organização vai depender em muito da eficácia do seu capital intelectual em poder criar novos conhecimentos, socializá-los na organização, e usar esse conhecimento para a obtenção dos melhores feitos possíveis.

A GC Organizacional, fundamentalmente, é a abordagem sobre como aplicar o conhecimento coletivo de todos os trabalhadores, para atingir objetivos específicos da organização. E a GC Pessoal tem, basicamente, o mesmo escopo, mudando o foco, que passa a iluminar os anseios e necessidades de cada indivíduo.

A GC é, essencialmente, a facilitação dos processos pelos quais o conhecimento é criado, compartilhado e utilizado pelas pessoas e pelas organizações, não se tratando, necessariamente, da criação de um novo desenho organizacional ou da introdução de um novo sistema informático, por exemplo.

Nesse aspecto, Probst, Raub, Romhardt (2002) dizem que,

[...] para sobreviver e competir na "sociedade do conhecimento", as empresas devem aprender a administrar seus ativos intelectuais. Provavelmente, há pouco de novo a ser dito sobre a administração dos fatores clássicos de produção; a gestão do conhecimento, entretanto, está apenas começando.

O conhecimento é o único recurso que aumenta com o uso.

[...] A "sociedade da informação" e a "economia do conhecimento" prognosticadas há muito tempo, agora estão surgindo como realidades tangíveis.

O conhecimento, contudo, ou a busca dele, em regra, oferece a descoberta de novos horizontes. Novos horizontes descortinam novos mundos. Em novos mundos, é muito provável que se encontre formas diferentes de se fazer ou realizar determinadas tarefas. O novo sempre suscita desafios e deflagra incertezas.

De acordo com Lastres e Albagli (1999),

[...] a busca pelo entendimento das transformações estruturais enfrentadas periodicamente pelas sociedades, [...] objetivando explicar as diferentes dinâmicas e padrões de geração, uso e difusão de tecnologias e outras inovações associadas [...], resultaram na criação do [...] arcabouço conceitual que caracteriza o que se convencionou chamar de paradigma tecno-econômico das tecnologias da informação - PTE, o qual indica [...] o resultado do processo de seleção de uma série de combinações viáveis de inovações (técnicas, organizacionais e institucionais), provocando transformações que permeiam toda a economia e exercendo importante influência no comportamento da mesma. [...] Cada novo paradigma tecno-econômico traz novas combinações de vantagens políticas, sociais, econômicas e técnicas, tornando-se o estilo dominante durante uma longa fase de crescimento e desenvolvimento econômico. 
Apoiados no conceito de paradigmas tecno-econômicos, e sob a égide da Organization for Economic Co-Operation and Development - $\mathrm{OCDE}^{2}$, alguns economistas, a exemplo de Giovanni Dosi, Chris Freeman e Carlota Perez, têm aprofundado seus estudos sobre as mudanças de paradigmas produzidas pela transmissão de conhecimento e pela introdução de inovações nas economias dos países, impulsionando a criação de atividades e setores econômicos dantes inexplorados. A maior consequência dessas transformações, talvez seja a prerrogativa de agregar valor aos indivíduos, exigindo deles, novas capacitações profissionais, e os submetendo a constantes desafios. Contudo, as bases para a formulação dessa teorização, provavelmente foram adquiridas em Schumpeter (1985), especialmente na sua Teoria dos Ciclos Econômicos, onde ele interpretou as principais ondas de crescimento econômico e transformações tecnológicas como “[...] sucessivas revoluções industriais [...]”, sustentando que o aumento precoce de novas tecnologias e inovações estabelecem períodos explosivos de crescimento, mas produz grandes turbulências e significativas incertezas, na economia.

Isso se deve ao fato de que essas quebras de paradigmas tecno-econômicos acontecem em meio a um clima de euforia tecnológica, onde surgem novas empresas, produtos e serviços, num ambiente ainda dominado por "velhas" empresas, resultando na inevitável existência de um tempo de grandes contrastes, que os economistas modernos chamam de fase de ajuste estrutural.

Perez (2005) considera as consequências dessas revoluções tecnológicas como "surtos" de desenvolvimento, que define como sendo:

[...] o processo pelo qual uma revolução tecnológica e o seu paradigma se propagam por toda a economia, conduzindo a mudanças estruturais na produção, distribuição, comunicação e consumo, bem como a mudanças profundas e qualitativas na sociedade. $\mathrm{O}$ processo evolui a partir de inícios de pequeno porte, em setores e regiões geográficas restritos, e acaba englobando a maior parte das atividades no país ou países, para, em seguida, difundi-la para pontos mais distantes, dependendo da capacidade das infraestruturas de transportes e comunicações. ${ }^{3}$

Perez (2005) ainda, reforçando sua teorização, apresenta as cinco revoluções tecnológicas de maior força em 200 anos (Quadro 1), onde se percebe que esses "surtos" foram provocados por ondas de introdução de inovações na economia.

\footnotetext{
${ }^{2}$ A OCDE entende que as economias dos países estão, de modo crescente, baseando-se no conhecimento e na informação. Para a Instituição, o conhecimento é agora reconhecido como uma força motriz de produtividade e crescimento econômico, conduzindo para um novo olhar sobre o papel da informação, tecnologia e aprendizado sobre a performance econômica dos países. Identificar as "melhores práticas" para a Economia Baseada no Conhecimento, atualmente é o ponto focal do trabalho da OCDE no campo da indústria, ciência e tecnologia.

${ }^{3}$ Tradução livre pelo autor.
} 
Quadro 1- Cinco Sucessivas Revoluções Tecnológicas, 1770 a 2000

\begin{tabular}{|c|c|c|c|c|}
\hline $\begin{array}{c}\text { Revolução } \\
\text { Tecnológica }\end{array}$ & $\begin{array}{c}\text { Período } \\
\text { (nome popular) }\end{array}$ & $\begin{array}{c}\text { Principal país ou } \\
\text { região }\end{array}$ & $\begin{array}{c}\text { O que provocou a } \\
\text { revolução }\end{array}$ & Ano \\
\hline \hline PRIMEIRA & $\begin{array}{c}\text { Revolução } \\
\text { Industrial }\end{array}$ & Inglaterra & $\begin{array}{c}\text { Abertura do Moinho } \\
\text { Arkwright em Cromford }\end{array}$ & $\mathbf{1 7 7 1}$ \\
\hline SEGUNDA & $\begin{array}{c}\text { Máquina vapor e das } \\
\text { ferrovias }\end{array}$ & $\begin{array}{c}\text { Inglaterra, } \\
\text { espalhando-se pela } \\
\text { Europa e USA }\end{array}$ & $\begin{array}{c}\text { Teste do motor a vapor } \\
\text { 'Rocket' no transporte } \\
\text { ferroviário Liverpool }- \\
\text { Manchester }\end{array}$ & $\mathbf{1 8 2 9}$ \\
\hline TERCEIRA & $\begin{array}{c}\text { Era do aço, } \\
\text { eletricidade e } \\
\text { engenharia pesada }\end{array}$ & $\begin{array}{c}\text { USA e Alemanha } \\
\text { suplantando a } \\
\text { Inglaterra }\end{array}$ & $\begin{array}{c}\text { Abertura da usina } \\
\text { siderúrgica Carnegie } \\
\text { Bessemer em Pittsburgh, } \\
\text { Pensilvânia }\end{array}$ & $\mathbf{1 8 7 5}$ \\
\hline QUARTA & $\begin{array}{c}\text { Era do petróleo, do } \\
\text { automóvel e da } \\
\text { produção em massa }\end{array}$ & $\begin{array}{c}\text { Alemanha disputando } \\
\text { a liderança do mundo, } \\
\text { depois se espalhando } \\
\text { para a Europa }\end{array}$ & $\begin{array}{c}\text { Primeiro Modelo T sai } \\
\text { da fábrica da Ford em } \\
\text { Detroit, Michigan }\end{array}$ & $\mathbf{1 9 0 8}$ \\
\hline QUINTA & $\begin{array}{c}\text { Era da Informação } \\
\text { e Telecomunicações }\end{array}$ & $\begin{array}{c}\text { USA, espalhando-se } \\
\text { pela Europa e Ásia. }\end{array}$ & $\begin{array}{c}\text { O microprocessador } \\
\text { Intel é anunciado em } \\
\text { Santa Clara, Califórnia }\end{array}$ & $\mathbf{1 9 7 1}$ \\
\hline
\end{tabular}

Fonte: Perez (2005)

Cada um desses "surtos" tecnológicos resultou numa interdependência sinérgica, que provocou transformações em cadeia, em vários setores industriais, como se vê no Quadro 2.

Quadro 2 - Os cinco "surtos": indústrias e infraestrutura

\begin{tabular}{|c|c|c|}
\hline Revolução Tecnológica & $\begin{array}{l}\text { Novas tecnologias e indústrias novas } \\
\text { ou redefinidas }\end{array}$ & Infraestrutura nova ou redefinida \\
\hline Revolução Industrial & $\begin{array}{c}\text { Indústria de algodão mecanizada, } \\
\text { ferro forjado, maquinaria }\end{array}$ & $\begin{array}{c}\text { Canais e hidrovias, estradas, roda } \\
\text { d'água }\end{array}$ \\
\hline $\begin{array}{l}\text { Máquina a vapor e } \\
\text { ferrovias }\end{array}$ & $\begin{array}{c}\text { Motores a vapor e maquinaria } \\
\text { (feitos de ferro, movidos a carvão), } \\
\text { mineração de ferro e carvão, } \\
\text { construção de estradas de ferro, } \\
\text { produção de vagões, energia a vapor } \\
\text { para várias indústrias (incluindo a } \\
\text { têxtil) }\end{array}$ & $\begin{array}{c}\text { Estradas de ferro (uso da energia a } \\
\text { vapor), serviço postal universal, } \\
\text { telégrafo (nacionalmente, ao longo } \\
\text { das estradas de ferro), grandes } \\
\text { portos, grandes estações e navegação } \\
\text { global a vela, encanamento de gás } \\
\text { urbano }\end{array}$ \\
\hline $\begin{array}{l}\text { Aço, eletricidade e } \\
\text { mecânica pesada }\end{array}$ & $\begin{array}{c}\text { Aço barato, química pesada, } \\
\text { indústria de equipamento elétrico, } \\
\text { cobre e cabos, alimentos enlatados, } \\
\text { papel e embalagem }\end{array}$ & $\begin{array}{l}\text { Navegação global a vapor, ferrovias } \\
\text { internacionais, telégrafo mundial, } \\
\text { telefonia (nacional), redes elétricas } \\
\text { para iluminação e uso industrial }\end{array}$ \\
\hline $\begin{array}{l}\text { Petróleo, automóvel e } \\
\text { produção em massa }\end{array}$ & $\begin{array}{l}\text { Automóveis em massa, petróleo e } \\
\text { combustíveis baratos, petroquímica, } \\
\text { equipamentos elétricos domésticos, } \\
\text { alimentação refrigerada }\end{array}$ & $\begin{array}{l}\text { Redes com rodovias, portos e } \\
\text { aeroportos, eletrificação universal, } \\
\text { telecomunicações globais (telefone, } \\
\text { telex) }\end{array}$ \\
\hline $\begin{array}{l}\text { Informação e } \\
\text { Telecomunicações }\end{array}$ & $\begin{array}{l}\text { Microeletrônica barata, } \\
\text { computadores, softwares, } \\
\text { telecomunicações, instrumentos de } \\
\text { controle, impacto sobre } \\
\text { biotecnologia e novos materiais }\end{array}$ & $\begin{array}{l}\text { Telecomunicações digitais globais } \\
\text { (cabos, fibras óticas, rádios, satélites), } \\
\text { Internet, e-mail, redes sem fios, } \\
\text { aceleração do transporte de bens. }\end{array}$ \\
\hline
\end{tabular}

Fonte: Perez (2005)

Vale salientar que a irrupção de cada inovação oportunizou a criação de poderosas e dinâmicas novas indústrias, acompanhadas de suas respectivas infraestruturas e significativas consequências, consolidando vasta gama de conhecimento, que foi sendo agregado e expandido, 
abrindo espaço para novas oportunidades organizacionais e pessoais. Assim, há de se perceber que a gestão organizacional desse novo mundo, caracterizado como uma sociedade do conhecimento, cujos cidadãos são chamados de trabalhadores do conhecimento, ou, ainda, ativistas do conhecimento, demanda, portanto, novas e eficazes formas de relacionamentos empresariais. A mobilização que hoje se espera dos gestores está fundamentada, precipuamente, no sentido de encontrar e utilizar recursos para vicejar as práticas negociais em um mundo novo e desafiante. Para tanto, há de se prospectar, no âmbito do conhecimento, as possibilidades de inovação das atividades empresariais, deixando de lado indicadores tradicionais de desempenho de curto prazo, que, por vezes, ocultam os desafios, as ameaças e as oportunidades para a organização.

Cabe aos executivos, então, o monitoramento permanente de seu conhecimento, agregandoo aos seus processos criativos, de tal sorte que a pesquisa básica e aplicada seja revigorada, que experimentos sejam realizados, e que a inovação e o aprendizado organizacional sejam ampliados. Com isso, uma nova fronteira empresarial é estabelecida, baseada em informações adequadas e pertinentes, as quais capacitam o executivo a construir significados e produzir conhecimento. Isso lhe permite abortar planos duvidosos, e adotar um comportamento decisório mais racional. Portanto, fazer do conhecimento uma ferramenta essencial na tomada de decisão é uma atividade eminentemente gerencial. Contudo, tomar decisão não é uma tarefa fácil, devido à overdose de informações que caracteriza a pós-modernidade, e também ao inter-relacionamento existente entre a razão e a emoção, que, ao gestor, pode intensificar essa dificuldade.

Lehrer (2009), que tem explorado a neurociência para explicar alguns aspectos da vida hodierna, diz que, no tocante à tomada de decisão, “[...] ironicamente, quando a emoção parece mais convincente - quando o cérebro está completamente certo de que dá para apostar todas as fichas - é a hora de fazer uma pausa para refletir. É preciso considerar outras possibilidades e outros cenários".

Vale então, questionar: Que conhecimento o executivo deve construir, para se tornar apto a identificar alternativas, discernir consequências e garantir o favorecimento da organização, face às ambiguidades e conflitos, visando os objetivos a serem atingidos?

Certamente, o conhecimento que leva ao abandono das interpretações genéricas, inova, suscita novos conhecimentos, gera decisões eficazes, e agrega valor pessoal e organizacional.

Cabe, então, outra pergunta: Como administrar todo o conteúdo a que se tem acesso atualmente, tendo em vista a mutabilidade do ambiente empresarial, e como usar essas informações de forma a criar possibilidades de escolhas, que se agreguem ao conhecimento adquirido, adaptando esses conhecimentos ao conhecimento existente, de forma a otimizar o processo decisório?

Entendemos ser este o ponto que pode trazer a conotação mais precisa, do que vem a ser GC, e, mais especificamente, GC Pessoal, temática precípua da presente análise. 
Sobre isso, Fleury, Oliveira Júnior (2008) dizem que,

[...] ao contrário do que vem sendo tratado por alguns autores, não é adequado pensar a gestão do conhecimento como um tópico essencialmente novo em administração de empresas, mas como um tema que deve ser entendido como desdobramento e aprofundamento de linhas teóricas de aprendizagem organizacional na teoria organizacional; é também fortemente influenciado pelos temas da gestão tecnológica e pelos estudos sobre cognição empresarial. [...] Assim, a gestão do conhecimento busca complementar lacunas e oferecer novas oportunidades de pesquisa e ação estratégica, na empresa, não contempladas pela abordagem da aprendizagem organizacional e outras abordagens na teoria organizacional.

Olhando-se para os conceitos dantes apresentados, encontra-se uma significativa consonância entre o que preconiza a teoria dos paradigmas tecno-econômicos, (mais especificamente os "surtos de desenvolvimento" de Carlota Perez); o referencial de Jonah Lehrer, de "considerar outras possibilidades e outros cenários"; e essa "visão da empresa baseada em recursos" que Maria Teresa Fleury e Moacir Oliveira Júnior apresentam. Todas elas apontam, em última instância, para a aprendizagem organizacional, destacando a importância do conhecimento como um recurso que pode dotar a empresa de uma vantagem competitiva essencial.

Devido, então, a todas as dificuldades inerentes a processos complexos como a criação de possíveis cenários futuros da arena de competição, resta ao executivo a alternativa de buscar incessantemente o aprimoramento de suas competências essenciais, que lhe garantirão a habilidade de proporcionar benefícios à empresa onde atua, e ao cliente, em particular. Cabe, então, ao executivo usar a GC organizacional e pessoal, como uma bússola que o guiará à práxis que manterá competitiva, a empresa detentora do recurso "conhecimento", seja na forma explícita e coletiva, armazenado em meios acessíveis, seja advindo do know-how e experiência dos seus funcionários.

No dizer de Mendes (2005),

[...] a Gestão do Conhecimento Organizacional influi diretamente nos processos finalísticos de qualquer organização e é responsável pela sobrevivência da empresa no mercado. Como a GC também pode apoiar a tomada de decisão, fornecendo as informações e o conhecimento necessário para a escolha da melhor opção aos executivos, fecha-se o ciclo em torno da sua importância.

No âmbito individual, cabe à GCI, indiretamente, o papel de apoio ao indivíduo em busca de seus objetivos de vida e sua felicidade, que são procedimentos muito semelhantes à função da GCO nas empresas. Muda apenas o escopo.

Seguindo na busca do aprofundamento da conceituação e compreensão de GC Organizacional e GC Pessoal, lança-se mão dos pensamentos dialéticos, mas complementares, dos autores que, na sequência, são destacados. 


\subsection{Os axiomas e o ponto de vista de Peter Senge}

A partir de estudos realizados por Arie de Geus ${ }^{4}$, que o tornou familiarizado com os conceitos de aprendizagem organizacional, no final da década de 70, Peter Senge passou a estudar sobre a baixa expectativa de vida e a diminuta vitalidade de empresas. Dessas reflexões, fundamentadas na teoria de De Geus (1997), que coloca a empresa na condição de "ser vivente", com uma vida que inicia e acaba, como acontece com seres humanos, que pensam, sentem, reagem, e, também, aprendem, Senge escreveu o seu livro seminal, A Quinta Disciplina, no qual apresenta a importância da aprendizagem organizacional para a ampliação da base de sustentação das empresas longevas e bem-sucedidas.

Senge (2008) aborda, de maneira crítica, o modus operandi da administração tradicional, desafiando a própria possibilidade de os gerentes poderem "controlar", de alguma forma, um sistema humano complexo, e argumenta que a maioria das intervenções gerenciais piora ainda mais as coisas, em vez de melhorá-las. E propõe como solução:

[...] o compromisso fundamental com o desenvolvimento de uma série de sofisticadas habilidades de aprendizagem individuais e coletivas que, em grande parte, estavam quase ausentes nas organizações tradicionais: alimentar a visão pessoal, e construir visões genuinamente compartilhadas; o trabalho com uma diversidade de "modelos mentais" e com os conflitos que, inevitavelmente, surgem deles, e a compreensão das causas sistêmicas subjacentes a questões complexas e altamente interdependentes (Senge, 2008).

A mensagem focal de Senge (2008), então, é:

[...] o imperativo da aprendizagem e da geração de conhecimento com ferramentas e métodos específicos que permitem novas formas de pensar e interagir. Pois, [...] nenhuma mudança organizacional significativa pode ser realizada sem que se efetuem profundas mudanças nas formas de pensar e interagir das pessoas. [...] nossas organizações funcionam da forma que funcionam por causa de nossa forma de pensar e de interagir. Só mudando nossa forma de pensar é que podemos modificar políticas e práticas profundamente enraizadas. Só mudando nossa forma de interagir poderemos estabelecer visões e compreensões compartilhadas, e novas capacidades de ação coordenada.

\subsection{Os axiomas e o ponto de vista de Chun Wei Choo}

Choo (2006) apresenta outra vertente na abordagem da GC, com foco em três perspectivas: a criação de significados, a construção do conhecimento e a tomada de decisão.

Inicialmente, pondera sobre o que ele entende por uma organização do conhecimento, hierarquizando sua concepção em dois níveis, e, com isso apresenta a essência do seu ensinamento:

[...] Em um primeiro nível, a organização do conhecimento é aquela que possui informações e conhecimentos que a tornam bem informada e capaz de percepção e discernimento. Num nível mais profundo, a organização do conhecimento possui

\footnotetext{
${ }^{4}$ Arie de Geus foi vice-presidente de planejamento da Royal Dutch Shell por trinta e oito anos, e realizou estudo sobre a longevidade das empresas. É o autor do livro The Living Company. É Diretor da Society for Organizational Learning da Sloan School of Management do MIT - Massachusetts Institute of Technology.
} 
informações e conhecimentos que lhe conferem uma vantagem, permitindo-lhe agir com inteligência, criatividade e, ocasionalmente, com esperteza. [...] A organização do conhecimento está preparada para sustentar seu crescimento e se desenvolver num ambiente dinâmico. Mas, porque sente e entende o ambiente que a cerca, a organização do conhecimento é capaz de se preparar para a adaptação com antecedência. Contando com a competência e experiência de seus membros, ela é capaz de constante aprendizado e inovação. Aplicando normas e rotinas aprendidas para a tomada de decisões, está preparada para empreender ações objetivas no momento apropriado. No coração da organização do conhecimento está a administração dos processos de informação, que constituem a base para criar significado, construir conhecimento e tomar decisões.

Esse é o cerne, portanto, do ensinamento desse autor. Suas observações apontam para a necessidade da existência de entendimento claro dos procedimentos humano-corporativos, por onde o fluxo de dados e informações transitam, e que, filtrados pelos processos cognitivo-perceptores, se transformam em conhecimento, competências, habilidades e atitudes.

Tem-se por certo, em síntese, que o objetivo maior e final do executivo na utilização da informação é a tomada de decisão.

As premissas básicas da teoria de Choo (2006) estão nos três caminhos pelos quais as organizações devem trilhar na utilização da informação: a identificação, dando sentido aos sinais advindos do ambiente e favorecendo a sua adaptação aos novos cenários; a mobilização do conhecimento e da experiência de seus membros, vivenciando um processo constante e contínuo de aprendizado e inovação; e a elaboração de roteiros sistematizados, que favoreçam a tomada de ações e decisões, com fundamentos fincados naquilo que os seus membros conhecem e em que acreditam.

Em suma, pode-se dizer que a essência da teoria em análise é:

[...] A criação de significado expressa o que é vital para a organização e para seus membros. A construção do conhecimento gera inovações e competências que ampliam o horizonte de escolha. Na tomada de decisões, os executivos são guiados por rotinas, regras e princípios heurísticos pessoais que simplificam e legitimam suas ações. (Choo, 2006).

\subsection{Os axiomas e o ponto de vista de Ikujiro Nonaka e Hirotaka Takeuchi}

Em sua construção teórica, esses autores afirmam que o sucesso atingido pelas empresas japonesas é fruto das competências e habilidades técnicas alcançadas pela geração e aproveitamento do conhecimento organizacional, construído pelas vias da valorização e da oportunização de atividades corporativas empreendedoras e inovadoras, tendo em mente que o acerto, geralmente, é resultado de várias tentativas mal-sucedidas.

Com vistas a uma maior compreensão do pensamento desses autores, explicita-se o que eles entendem por criação de conhecimento organizacional:

[...] Por criação do conhecimento organizacional queremos dizer a capacidade que uma empresa tem de criar conhecimento, disseminá-lo na organização e incorporá-lo a produtos, serviços e sistemas (Nonaka e Takeuchi, 1997). 
[...] O conhecimento tácito foi deixado de lado como componente crítico do comportamento humano coletivo. Ao mesmo tempo, entretanto, o conhecimento tácito é uma fonte importante da competitividade das empresas japonesas. É ele, provavelmente, o principal motivo da competitividade das empresas japonesas. E é provavelmente o principal motivo pelo qual a gerência japonesa é vista como um enigma pelos ocidentais (Nonaka e Takeuchi, 1997).

Para Nonaka e Takeuchi (1997) o indivíduo é autor e ator do processo de criação do conhecimento organizacional, porque ele interage com a empresa, por intermédio do conhecimento. Assim, sugerem que a criação do conhecimento ocorre em três planos: o do indivíduo, o do grupo e o da organização. Dessa feita, a abordagem tem dois elementos centrais: as formas de interação do conhecimento e os níveis de criação do conhecimento. Nessa perspectiva, então,

[...] As duas formas de interação - entre o conhecimento tácito e o conhecimento explícito e entre o indivíduo e a organização - realizarão quatro processos principais da conversão do conhecimento que, juntos, constituem a criação do conhecimento: (1) do tácito para o explícito; (2) do explícito para o explícito; (3) do explícito para o tácito; e (4) do tácito para o tácito. (Nonaka e Takeuchi, 1997).

Portanto, para esses autores, “[...] a não ser que o conhecimento compartilhado torne-se explícito, não pode ser facilmente alavancado pela organização como um todo”.

\section{Tomada de decisão empresarial}

A tomada de decisão é, indubitavelmente, a tarefa que mais caracteriza as atividades diuturnas de um executivo. Não importa o nível hierárquico em que esteja atuando, todos os executivos de uma empresa estão, a cada momento, analisando alternativas, fazendo escolhas e tomando decisões.

Essas decisões estabelecem um curso de ação empresarial que impacta o tomador da decisão e todos os níveis hierárquicos que estejam sob seu raio de abrangência.

Desta feita, uma decisão é a eleição de um curso de ação, no intuito de se atingir, com efetividade, objetivos e metas programadas, com o mínimo de contradições, maximizando consequências positivas. Decisões, então, podem ser definidas como o resultado da adoção de cursos de ação, as quais facilitam a determinação de atividades, à medida que definem e elaboram propósitos, alocam e autorizam o dispêndio de recursos.

Por se tratar de assunto que envolve, primordialmente, o comportamento humano, a busca por um modelo para tomada de decisões assertivas, que se aproxime ao máximo da plenitude das possibilidades de soluções para a organização tem despertado o interesse dos estudiosos do tema, na busca de novas ferramentas para encontrar padrões que combatam a dualidade e a ambiguidade, lançando mão das informações, com consciência da complexidade do problema, tendo acesso a pontos de clareza, de modo a conseguir harmonia entre o caos e a ordem pessoal e organizacional. 
Tendo como foco uma possível medição das dificuldades dos executivos numa tomada de decisão, procura-se neste ponto deste trabalho, compreender alguns dos principais modelos para tomada de decisões administrativas.

\subsection{Modelos de tomada de decisões}

O processo de tomada de decisões gera uma grande sobrecarga emocional nos executivos, pelo fato de que alguns aspectos podem gerar erros de julgamento. A incerteza, o risco e o conflito, aliados a fatores pessoais influenciadores e motivadores de uma determinada escolha, têm sido a força motriz que tem provocado o surgimento de tantos modelos para processos decisórios.

Apresenta-se e se compara, em seguida, os quatro modelos considerados, no mundo acadêmico e empresarial, como sendo os que mais se aproximam das respostas aos problemas organizacionais surgentes das constantes mudanças por que passa o cenário corporativo: o modelo racional desenvolvido por Simon e March (1993), Cyert e March (1992); o modelo processual de Mintzberg, Raisinghani e Théorêt (1976); o modelo político de Allison (1971); o modelo anárquico de Cohen, March e Olsen (1972); e alguns modelos contemporâneos de tomada de decisões.

\subsubsection{Modelo racional}

Fundamenta-se na teoria de March e Simon (1993) e Cyert e March (1992), e se caracteriza por ser orientado para objetivos, e guiado por problemas, e o comportamento de escolha, por parte do decisor, ser um comportamento regulado por normas e rotinas, de modo que o executivo e a organização, por conseguinte, possam agir de uma maneira procedimental e intencionalmente racional.

Segundo Simon $(1957,1970)$, a

[...] tomada de decisões numa organização é limitada pelo princípio da racionalidade limitada: A capacidade da mente humana de formular e solucionar problemas complexos é muito pequena, comparada com o tamanho dos problemas cuja solução requer um comportamento objetivamente racional no mundo real - ou mesmo uma aproximação razoável a essa racionalidade objetiva.

A pedra angular dessa teoria está no fato de que os pontos basilares da estrutura e da função organizacional são derivados de características dos processos de solução de problemas e da escolha racional, dado que os limites da mente humana e a complexidade dos problemas que ela enfrenta, leva a que a tomada de decisões requeira simplificações, como citado em Simon $(1957,1970)$.

O modelo de tomada de decisões elaborado por Cyert e March (1992), por sua vez, fundamenta-se em quatro conceitos, como está ilustrado na Figura 1: 
Figura 1- Modelo racional de tomada de decisões

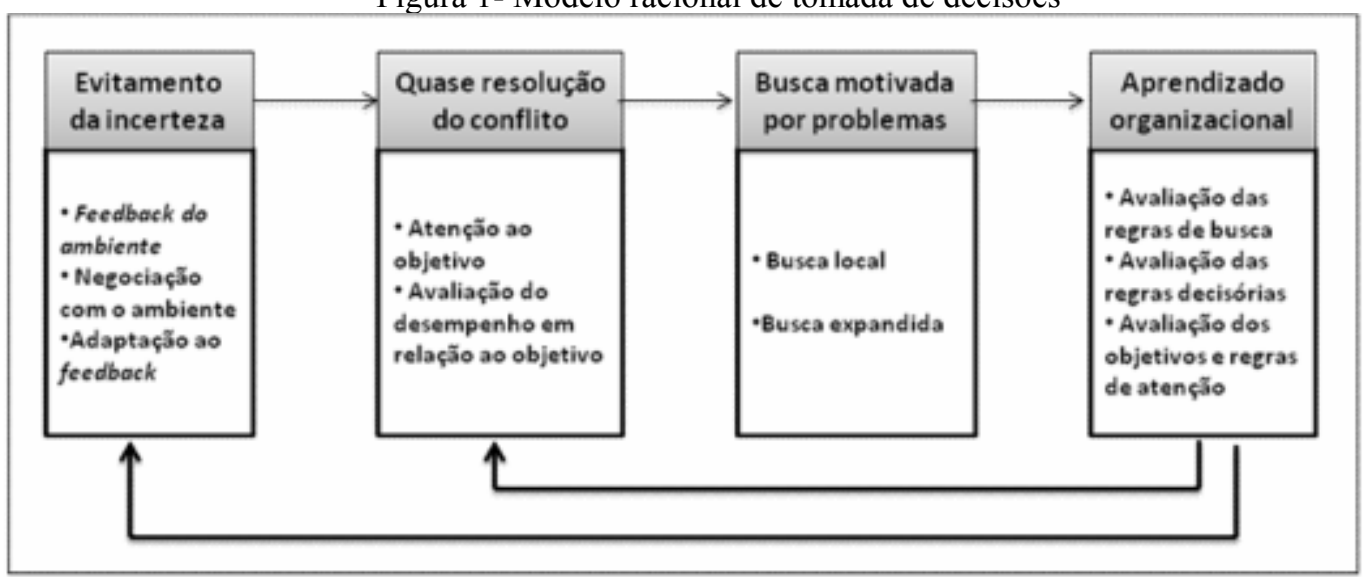

Fonte: Cyert e March (1992)

\subsubsection{Modelo processual}

Mintzberg et al. (1976) elaboraram as bases desse modelo, fundamentando-o em três fases decisórias principais, três rotinas de apoio às decisões e seis grupos de fatores dinâmicos, os quais se ilustra na Figura 2.

Figura 2 - Modelo processual de tomada de decisão estratégica

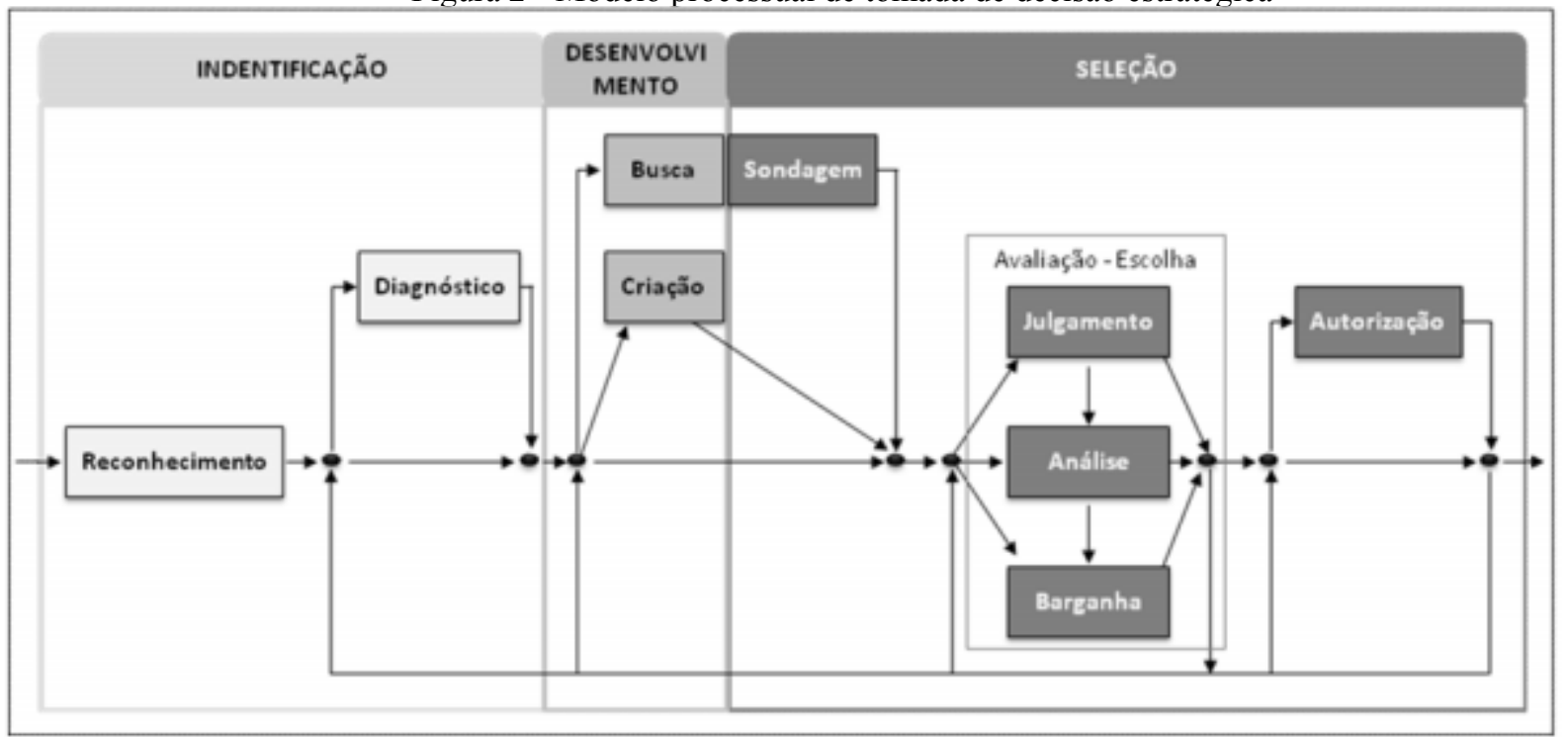

Fonte: Mintzberg et al. (1976)

Explicando o modelo processual, Mintzberg et al. (1976) sugerem,

[...] As três fases decisórias são identificação, desenvolvimento e seleção. A fase de identificação reconhece a necessidade de tomar uma decisão e desenvolve a compreensão das questões implicadas na decisão. A identificação consiste em rotinas de reconhecimento e rotinas de diagnóstico. A necessidade de uma decisão é definida como uma necessidade de informação. [...] $\mathrm{Na}$ rotina de diagnóstico, a administração tenta compreender os estímulos que desencadeiam a decisão, assim como as relações causais relevantes para a situação decisória. [...] A fase de desenvolvimento leva ao desenvolvimento de uma ou mais soluções para um problema ou crise, ou à criação de uma oportunidade. Consiste em rotinas de busca - busca na memória, busca passiva (esperar alternativas não procuradas), busca-armadilha (ativar geradores de busca, ex., fornecedores), e busca ativa (procura ativa de alternativas); e rotinas de criação - envolvem o desenvolvimento de solução customizada ou modificação de alternativa convencional existente. [...] A fase de seleção 
avalia as alternativas e escolhe uma solução para um compromisso com a ação. Consiste em rotinas de sondagem - eliminam o que não é viável, reduzindo o número de alternativas a serem consideradas; rotinas de avaliação-escolha usam julgamento, barganha ou análise para chegar a uma escolha. No julgamento, o indivíduo faz a sua escolha pessoal. Na barganha, a escolha é feita em grupo, onde há objetivos e interesses conflitantes, com cada participante exercendo seu próprio julgamento. $\mathrm{Na}$ análise, as alternativas e suas consequências são avaliadas segundo um conjunto de critérios, e a escolha final é feita por barganha ou por julgamento; e as rotinas de autorização - definem uma trilha por meio da hierarquia organizacional para que a decisão obtenha apoio interno e externo e para garantir recursos para a sua implementação.

\subsubsection{Modelo político}

Choo (2006) analisando este modelo produzido por Graham T. Allison (1971) a partir de seus estudos sobre as decisões tomadas na crise dos mísseis de Cuba em 1962, diz que Allison utilizou o modelo racional e o modelo processual, mas, chegou à conclusão de que esses dois modelos não eram aplicáveis àquela situação, porque não explicavam plenamente $\mathrm{o}$ desenvolvimento do processo de tomada de decisão que havia sido implementado as ações adotadas. “[...] Fazia-se necessário um modelo político, que deixasse claro que as ações e decisões são também resultado da barganha entre jogadores que perseguem seus interesses e exercem a influência de que dispõem" (Choo, 2006).

Em sua análise do modelo político de Allison (1971), Choo (2006) diz que

[...] As ações e decisões podem então ser analisadas com base nas respostas a uma sequência de quatro perguntas:

1. Quem são os jogadores?

2. Quais as posições dos jogadores?

3. Qual a influência de cada jogador?

4. Como a posição, a influência e os movimentos de cada jogador combinam-se para gerar decisões e ações?

No entendimento de Allison (1971), os jogadores, nesse jogo de poder, são os envolvidos no processo decisório, e seus objetivos e possíveis ações podem provocar um determinado impacto no curso dos acontecimentos. Por posição dos jogadores pode-se depreender que são aquelas, determinadas pela forma como cada jogador analisa e vê determinada questão. Essa posição, em geral, é adotada sob a influência de seu interesse, ou ponto de vista, e pelas reações que lhe são desencadeadas, em função de prazos e ocorrências. Em geral, a adoção de uma posição diante de uma situação parte de uma decisão baseada em percepção, que, inevitavelmente, é limitada pelos aspectos emocionais e cognitivos inerentes ao indivíduo participante. "[...] A sobreposição dos interesses das pessoas, do grupo e da organização constitui a posição em favor da qual o indivíduo joga o jogo da decisão".

Ao definir a influência de cada jogador, Allison (1971) reporta-se ao fato de que essa é “[...] uma questão de poder, que ele acredita ser resultado de vantagens barganhadas, da capacidade e da vontade de usar essas vantagens e da maneira como os outros jogadores veem esses dois 
elementos". Para, então, manifestar seu movimento, sua posição, sua influência, e a combinação desses três pontos para a geração das decisões e ações, o jogador “[...] tem que ocupar posições ligadas aos canais que levem à ação, que são os meios formais de interferir em alguma questão específica" Allison (1971).

\subsubsection{Modelo anárquico}

Fundamentando-se em outros modelos para tomada de decisão organizacional, Cohen et al. (1972) propõem uma nova forma de ver as organizações. Eles sugerem que organizações são como anarquias organizadas, nas quais as situações de decisão são caracterizadas por preferências problemáticas, tecnologia obscura e participação fluida.

Para qualificar, então, a sua teoria sobre o modelo anárquico no processo decisório, Cohen et al. (1972) observaram que os modelos racional e processual podem ser caracterizados como sendo sequências estruturadas, destinadas à solução de problemas, contudo, o comportamento real na tomada de decisão às vezes parece ser aleatório e desconexo, determinado mais pelas soluções disponíveis, pelos interesses dos participantes e pelas situações existentes. Esclarecendo esse pensamento, dizem que

[...] Embora as organizações possam muitas vezes ser vistas como veículos para a solução de problemas ou estruturas dentro das quais os conflitos são resolvidos por meio de barganhas, elas também oferecem procedimento com os quais os participantes chegam a uma interpretação do que estão fazendo e do que já fizeram no processo de fazê-lo. Desse ponto de vista, a organização é um conjunto de escolhas procurando por problemas, questões e sentimentos procurando situações de decisão em que possam se manifestar, e pessoas que tomam decisões procurando trabalho (Cohen et al., 1972).

No entender de Cohen et al. (1972), uma circunstância que demanda uma tomada de decisão pode ser comparada a uma lata de lixo, na qual uma diversidade de problemas e soluções são lançadas pelos decisores, à medida em que são gerados. A decisão, portanto, acontece quando problemas, soluções, participantes e oportunidades de escolha coincidem.

[...] uma oportunidade de escolha pode ser vista como uma lata de lixo na qual vários tipos de problemas e soluções são atirados pelos participantes à medida que vão sendo gerados. A mistura de lixo numa única lata depende da mistura de latas disponíveis, dos rótulos colados às diversas latas, de que tipo de lixo está sendo produzido, e da velocidade com que o lixo é coletado e removido de cena.

Cohen et al. (1972) indicam que no processo anárquico do modelo da lata de lixo de tomada de decisão, decisões são tomadas de três formas: por resolução, por inadvertência e por fuga.

É importante destacar que apesar de o processo anárquico de tomada de decisão ter uma aparência de improdutividade, o modelo da lata de lixo não aponta para a disfuncionalidade, pelo fato de ser possível que se tome decisões sob condições incertas e conflituosas, onde os objetivos 
são ambíguos, os problemas não são bem compreendidos e os que tomam as decisões dedicam tempo e energia variáveis aos problemas.

Em resumo, o modelo anárquico descreve situações em que tanto os objetivos quanto os problemas são ambíguos. Os participantes jogam seus problemas e soluções em situações de escolha, que atuam como receptáculos onde as soluções são ligadas a problemas, dependendo do ritmo, do interesse, das forças externas etc. (Choo, 2006).

\subsection{Modelos contemporâneos para tomada de decisões}

Pretende-se, ao se inserir neste estudo um modelo de processo decisório moderno, (mas ainda com reduzida aplicabilidade prática comprovada), não somente reforçar a significância da informação e do conhecimento para a tomada de decisão efetiva e assertiva, como também fazer contraponto com outros modelos contemporâneos que se fazem presentes no contexto empresarial.

Baseado no conceito de business intelligence - um conjunto de tecnologias e processos que utilizam dados para compreender e analisar o desempenho do negócio, Thomas Davenport e Jeanne Harris (2007), desenvolveram um modelo que chamaram de competição analítica. De acordo com esses autores, inteligência analítica é um subsistema que passou a ser chamado de business intelligence, sendo definido como a

[...] utilização extensiva de dados, análises quantitativas e estatísticas, modelos explicativos e preditivos e gestão baseada em fatos para orientar decisões e ações. A inteligência analítica pode ser utilizada para as decisões humanas ou pode orientar decisões totalmente automatizadas.

Segundo esses autores, o modelo de tomada de decisão fundamentado na inteligência analítica não se trata de um processo decisório com base na tecnologia analítica da informação, dado que "[...] os aspectos humanos e organizacionais da liderança analítica é que são os elementos verdadeiramente diferenciadores".

Este modelo enfoca, em sua essência, as ferramentas administrativas que permitam a execução dos negócios com efetividade, e facilitem o processo de tomada de decisões, tornando-o o mais inteligente e assertivo possível. Para Davenport e Harris (2007), “[...] boas decisões costumam envolver dados sistematicamente reunidos, e uma boa análise desses dados".

Um outro modelo de tomada de decisão, proposto por Gladwell (2005), baseia-se na intuição, por meio do qual, o autor afirma que "[...] decisões tomadas muito depressa podem ser tão boas quanto decisões tomadas de forma cautelosa e deliberada".

A teorização desse modelo se fundamenta basicamente no que Gladwell (2005) chamou de "fatiar fino" - "[...] a capacidade do nosso inconsciente para encontrar padrões em situações e comportamentos com base em fatias muito finas de experiências". Gladwell (2005) argumenta, no 
entanto, que a intuição somente representa um bom guia para a ação, quando é apoiada por muitos anos de experiência.

Klein (1998) também apresenta argumentos similares para fundamentar seu modelo de tomada de decisão, ao qual chamou de naturalista - “[...] um estudo de como as pessoas utilizam a sua experiência para tomar decisões" - argumentos esses adquiridos de estudos realizados para compreender como as pessoas lidam com todas as confusões e pressões típicas dos ambientes em que estão inseridas, tais como informações que desaparecem, restrições de tempo, objetivos vagos e condições alteráveis. Como resultado de suas pesquisas, Klein (1998) afirma ter descoberto

[...] que as pessoas se baseiam num amplo conjunto de capacidade que são fontes de poder ${ }^{5}$. As fontes de poder convencionais incluem pensamento lógico-dedutivo, análise das probabilidades e métodos estatísticos. Todavia, as fontes de poder necessárias em ambientes naturais não são, por regra, analíticas - o poder da intuição, da simulação mental, da metáfora e de contar histórias. O poder da intuição possibilita-nos avaliar rapidamente uma situação. $O$ poder da simulação mental deixa-nos imaginar o curso que uma ação poderia tomar. O poder da metáfora permite que nos baseemos na nossa experiência, sugerindo paralelos entre a situação atual e algo que já vivemos. O poder de contar histórias ajuda-nos a consolidar as nossas experiências, de modo a torná-las disponíveis no futuro, quer para nós próprios, quer para outros.

Apresentando outra abordagem sobre o mesmo tema, Ariely (2009) diz que

[...] Hoje, estamos pagando um preço terrível pela fé inamovível no poder da mão invisível. Estamos despertando, de forma dolorosa, para a falsidade da teoria econômica convencional - a tese de que o ser humano é capaz de tomar decisões invariavelmente racionais e de que mercados e instituições têm, em seu conjunto, o saudável poder de se autorregular. [...] Finalmente começamos a entender que a irracionalidade é a verdadeira mão invisível por trás de decisões tomadas pelo homem.

[...] a empresa hoje vê como é importante se proteger de premissas falsas. Munida do conhecimento de que o ser humano é movido por vieses cognitivos dos quais nem sequer está ciente (uma verdadeira mão invisível, se já existiu uma), a empresa pode começar a se defender melhor da estupidez e do desperdício.

Diante desses conceitos, cabe se questionar qual o modelo de tomada de decisão que promove efetividade e assertividade de resultados.

\subsection{Decisão efetiva e decisão assertiva: conceituação}

Nos dias atuais, quando, em diversos setores da economia, as mudanças são céleres, exigentes e, por vezes, complexas, apenas o conhecimento técnico, já não é o atributo mais importante de um executivo. Desse gestor do século XXI espera-se habilidade no trânsito internacional, visão estratégica acentuada, grande flexibilidade e capacidade adaptativa, foco nos clientes finais, e, em especial, competências para formar e gerenciar equipes de alto desempenho. Todos esses requisitos, e mais tantos outros que se fazem necessários no papel gerencial,

\footnotetext{
${ }^{5} \mathrm{O}$ termo fonte de poder, segundo Klein (1998), foi criado na ciência cognitiva por Doug Lenat, pesquisador na área da inteligência artificial. Lenat usou o termo para designar as capacidades analíticas de decomposição do problema em elementos e executar operações básicas nestes elementos como uma forma de resolver o problema.
} 
irremediavelmente trafegam por um processo de decisão repleto de informações dúbias, que podem obstacularizar a consecução dos resultados desejados. Pequenos erros, ou, melhor dizendo, "não acertos", podem levar a prejuízos, ou mesmo a crises de proporções sócio-econômicas consideráveis. Portanto, diante de um cenário econômico-corporativo tão exigente como o atual, uma persecução contínua e acurada dos fatos que acontecem se torna essencial para a obtenção do conhecimento das tendências, e há de se pensar quão importante se torna a efetividade e a assertividade de uma decisão.

Mas, o que vem a ser uma decisão efetiva e assertiva no contexto empresarial?

Para Ferreira (2009), a efetividade diz respeito à capacidade de algo produzir efeito real, atingir os resultados esperados, cuja realidade pode ser verificada, por ser incontestável, além de não ter interrupção e ser permanente.

Por dedução, então, uma decisão efetiva é aquela que produz efeito real, atinge os objetivos e metas que se estabeleceram como ideais, dentro de padrões de economicidade que a validem como incontestavelmente bem-sucedida, exequível, permanente e que funcione como uma solução para determinado problema empresarial. Por decisão assertiva assume-se como sendo aquela que enuncia uma posição verdadeira e é considerada como tal, tendo sua validação refletida na disseminação de sua aceitação pelos diversos segmentos hierárquicos da empresa.

Portanto, considera-se, a partir do entendimento dos conceitos supracitados, que uma decisão efetiva e assertiva é aquela que se reveste de efeitos reais e permanentes, os quais são inegavelmente verdadeiros, e cuja economicidade é exequível e perfeitamente mensurável, se afasta da ambiguidade da informação, e está estruturada em processos que facilitem esse afastamento.

Certamente, há de se levar em conta que essa concepção conceitual indica o ponto ótimo de uma decisão dentro de um processo decisório, e não se espera que todas as decisões efetivas e assertivas, obrigatoriamente, atendam plenamente a todos os requisitos postos nessa definição. Considera-se como imprescindível para a compreensão dessa abordagem, que se tenha em mente as diversas dificuldades relativas à obtenção de informações precisas, que proporcionem a criação de significado e produzam o conhecimento ótimo e permita uma perfeita tomada de decisão.

Depreende-se, portanto, que uma decisão plenamente efetiva e totalmente assertiva exige a busca de informações que a organização, geralmente, não tem envergadura para obter, e um processamento de informação que o ser humano não está apto a executar. Como, então, um executivo pode fazer frente a todo esse emaranhado de circunstâncias e incertezas que se lhe apresentam a todo instante, e tomar decisões efetivas e assertivas?

Tenta-se, então, fundamentando-se em modelos pré-existentes, propor um modelo que estabeleça parâmetros pertinentes e viáveis, que venham a contribuir para uma tomada de decisão efetiva e assertiva, pelos executivos. 


\subsection{Decisão efetiva e assertiva: um modelo}

Segundo Simon (1970), “[...] todo comportamento envolve seleção consciente ou inconsciente de determinadas ações, entre aquelas que são fisicamente possíveis para o agente e para aquelas pessoas sobre as quais ele exerce influência e autoridade”. Seguindo essas linhas de raciocínio, entende-se que se possa buscar atingir o grau de uma decisão efetiva e assertiva, adotando o curso de ação que se propõe e que está ilustrado na Figura 3.

Figura 3 - Modelo de tomada de decisão efetiva e assertiva

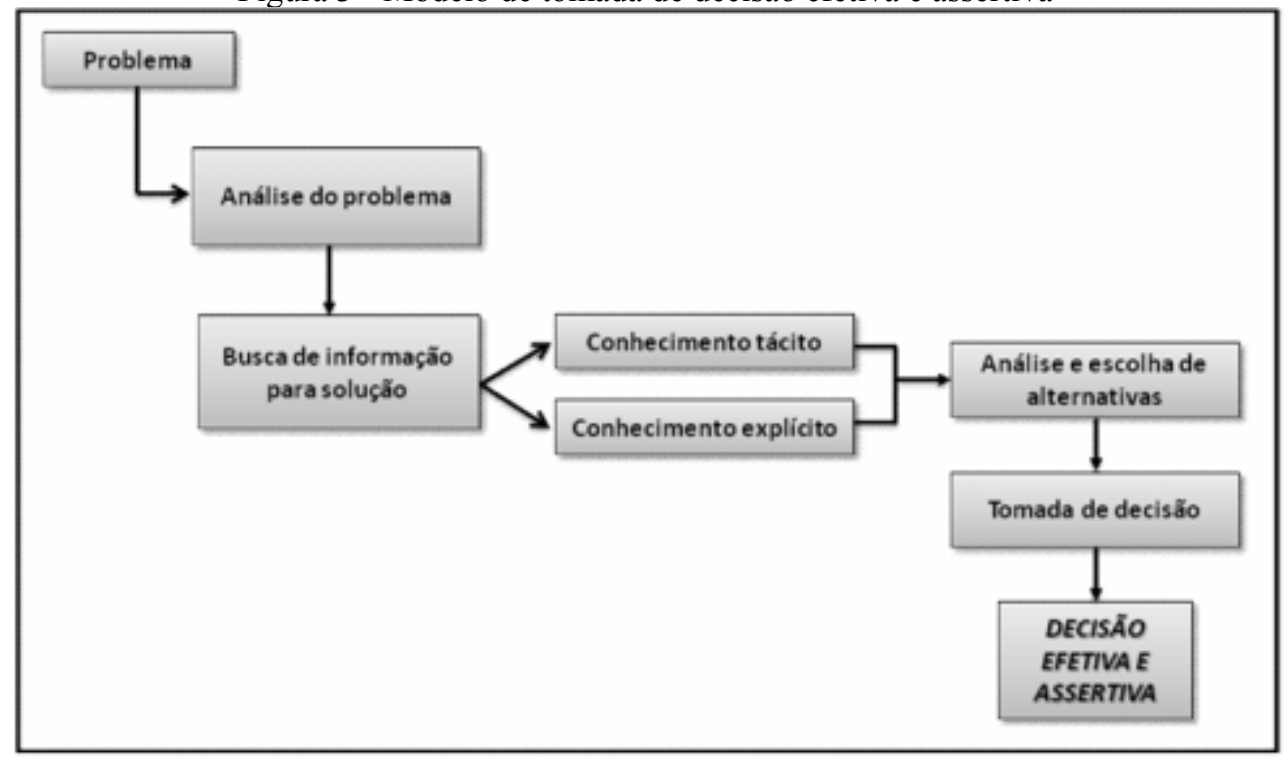

Fonte: Elaborado pelo autor (2010)

O modelo que se sugere, concentra-se inicialmente na percepção de que há um problema a ser solucionado. Diante da assimilação, da existência desse problema, o executivo será compelido a buscar as soluções modificadoras do contexto em que se encontra. Essa busca de soluções passará, inevitavelmente, pela acurada análise e interpretação do problema em si - sua abrangência, sua complexidade, seus possíveis impactos, e as consequências sócio-organizacionais que essa situação pode acarretar à empresa.

Mapeada a visão do contexto e a compreensão do ambiente complicador, faz-se necessário a busca dos dados e informações que propiciem o estabelecimento de objetivos claros, e aponte para alternativas de solução.

Dessa pesquisa serão obtidos dados brutos e informações dúbias, tornando-se necessário a interpretação da pertinência e da aplicabilidade dessas informações à solução desejada, capacitando o executivo à escolha daquelas que se apresentam como possibilidades viáveis à construção de alternativas de solução.

Contudo, a caracterização dessa decisão como efetiva e assertiva somente poderá ser feita pela avaliação e acompanhamento do curso de ação adotado, para a constatação, ou não, da efetividade do resultado obtido ao final. 


\section{Metodologia da pesquisa}

O método utilizado para realizar esta pesquisa foi o survey, o qual, com o objetivo de identificar a razão pela qual os executivos tomam ou não determinada decisão; para conhecer o processo pelo qual esses executivos passam antes da tomada da decisão, para saber quanto tempo levam para tomá-la, o que eles consideraram, quando e onde a decisão foi tomada.

O universo utilizado para se realizar esta pesquisa foram as empresas em operação no município de Vinhedo, corresponde a 2.500 (duas mil e quinhentas), tendo como ano-base, 2008, o qual ocupa o quadragésimo primeiro lugar no ranking de 645 (seiscentos e quarenta e cinco) municípios do Estado de São Paulo por valor agregado, e se posiciona no centésimo, vigésimo sétimo lugar quando a referência é o Brasil e seus 5.565 (cinco mil, quinhentos e sessenta e cinco) municípios. (Assessoria Econômico-Financeira da Prefeitura Municipal de Vinhedo, 2010).

A coleta de dados foi efetuada por meio de roteiro de entrevistas, com perguntas fechadas e abertas, aplicadas a 30 entrevistados, obtendo-se $66,67 \%$ de retorno dos questionários, visando-se obter as respostas que conferem validade às considerações a respeito do tema aqui analisado.

A análise dos dados coletados foi feita por meio da contextualização da amostra, da análise da variável GC Pessoal e da análise da variável Tomada de Decisão Empresarial.

\section{Análise dos dados da pesquisa}

Para se identificar a frequência da prática da GC organizacional, utilizou-se da seguinte questão:

1) Qual a frequência que retrata a GC praticado em sua empresa?

É significante a frequência com que a GC é realizada no ambiente corporativo, pois: $74 \%$ dos respondentes afirmam que é praticada na empresa, sendo que frequentemente corresponde a $47 \%$, e muito frequentemente corresponde a $27 \%$ das respostas.

Para se saber o "por que" da resposta dada, obteve-se como respostas mais frequentes:

- Geração de novas competências pessoais e corporativas;

- Aprimoramento dos processos organizacionais;

- $\quad$ Prevenção de perdas;

- $\quad$ Conhecimento das ações da concorrência e das mudanças no mercado;

- $\quad$ Socialização do conhecimento tácito;

- Transformação de conhecimentos adquiridos, em novos conhecimentos. 


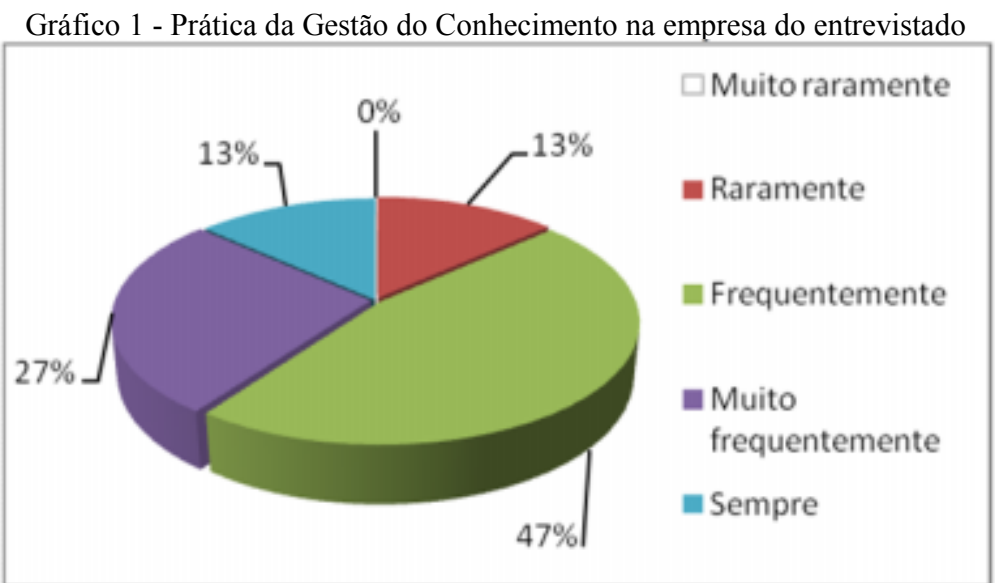

Fonte: Pesquisa de campo realizada pelo autor (2010)

Com relação à busca da GC pessoal, aplicou-se a seguinte questão:

2) Qual a frequência que retrata a GC na sua vida pessoal?

$86 \%$ dos respondentes afirmam que a praticam em suas vidas pessoais, sendo, frequentemente 33\%, muito frequentemente 33\%, e sempre $20 \%$. Os entrevistados podem estar entretecendo seus conceitos de competências com GC, contudo, nota-se que o conhecimento tácito está presente nas respostas, pois é possível se detectar isto quando se abre a questão:

- Busca nas antigas experiências, sob a ótica dos novos conhecimentos;

- $\quad$ Aprimoramento pessoal e profissional;

- Qualificação das tomadas de decisão pessoais;

- $\quad$ Apropriação pessoal do conhecimento externo;

- $\quad$ Fundamentação em informações para a tomada de decisão; para se manter atualizado no mundo globalizado e suas mudanças frequentes.

Gráfico 2 - Prática da Gestão do Conhecimento pessoal do entrevistado

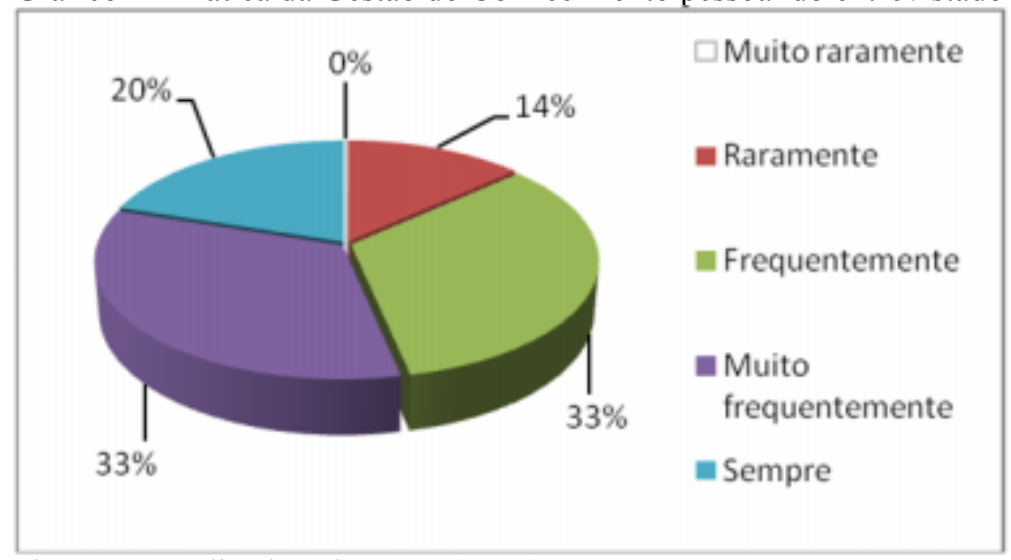

Fonte: Pesquisa de campo realizada pelo autor (2010)

Quanto à utilização do tipo de conhecimento, se tácito ou explícito, no processo decisório, fez-se a seguinte questão:

3) Nas suas tomadas de decisão organizacional, o que você mais utiliza? 
$70 \%$ de uso do conhecimento tácito, e 30\% do conhecimento explícito, refletem o que pode ser observada no meio corporativo brasileiro: a incipiente elaboração de documentos que norteiem processos organizacionais, sendo privilegiado o conhecimento tácito, no momento das tomadas de decisões.

Quando, se abre a questão, obteve-se o seguinte:

- Decisões embasadas em experiências pessoais dão mais segurança;

- $\quad$ O conhecimento explícito validado pelo conhecimento tácito permite decisões mais assertivas;

- $\quad$ O conhecimento tácito é mais condizente com o dia-a-dia;

- $\quad$ O conhecimento tácito é fruto de um longo aprendizado profissional e de experiência anteriores.

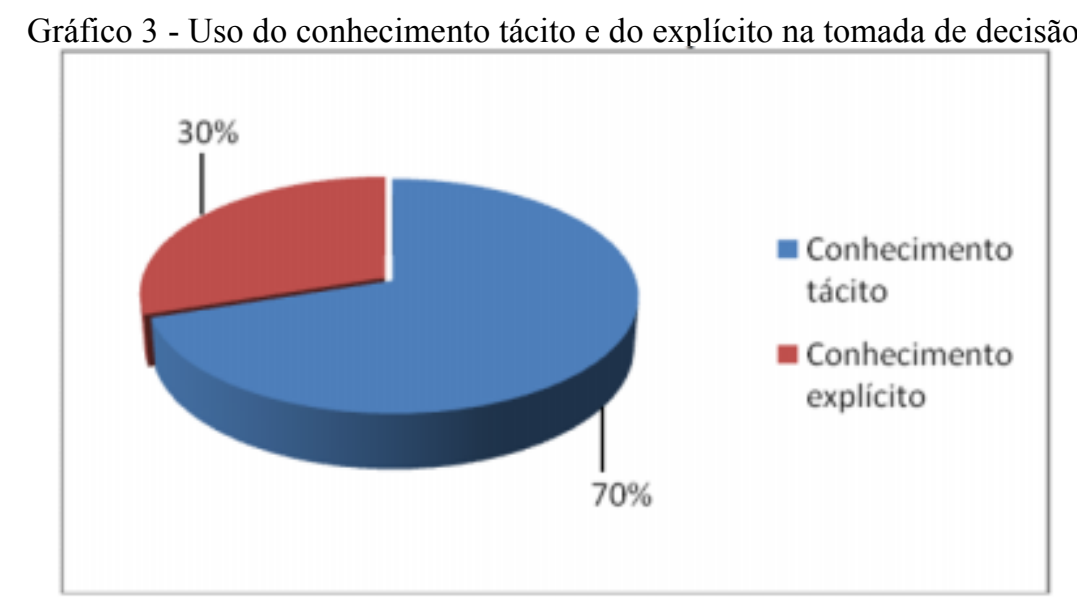

Fonte: Pesquisa de campo realizada pelo autor (2010)

Sobre a participação do conhecimento, tácito e explícito na visão estratégica da empresa, perguntou-se sobre os elementos influenciadores da posição competitiva da empresa, com a seguinte questão:

4) A posição competitiva atual de sua empresa é mais influenciada por:

Investigando a GC Organizacional como ativo estratégico, depara-se com o fato de o foco estar mais na arena competitiva, do que no capital intelectual corporativo.

Essa percepção pode ser justificada, quando se analisa o fato de que $80 \%$ do total das respostas dos entrevistados indicam que o foco está no mercado e que estão assim distribuídos: 44\% distinguiram a qualidade do produto; 20\% citaram a marca; e 16\% optaram pela diversidade de produtos como sendo os principais influenciadores da posição competitiva organizacional, o que se demonstra no Gráfico 4. 
Fonte: Pesquisa de campo realizada pelo autor (2010)

Sobre o papel do conhecimento como elemento influenciador no processo decisório, fez-se a pergunta seguinte:

5) Qual o nível que retrata o quanto o conhecimento organizacional, presente na sua empresa, tem papel preponderante e influenciador do processo de tomada de decisão.

$47 \%$ dos entrevistados entendem que o conhecimento explícito exerce força influenciadora no momento da decisão, enquanto que $20 \%$ acreditam ser regular, $26 \%$ consideram suficientes, e $7 \%$ disseram ser insuficientes.

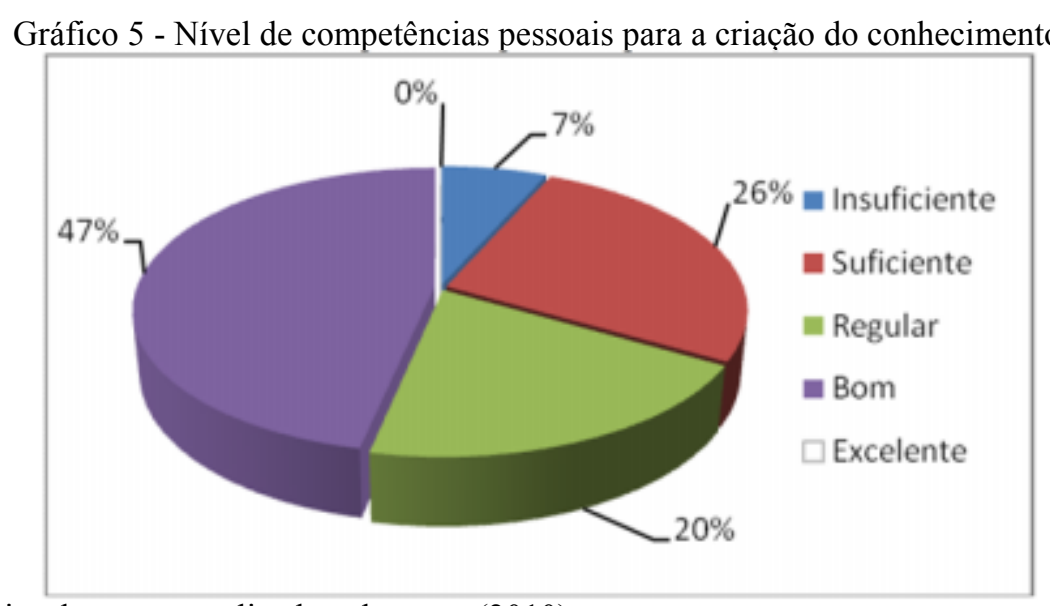

Fonte: Pesquisa de campo realizada pelo autor (2010)

Sobre como o executivo discerne o papel do seu conhecimento tácito no processo decisório, sob o ângulo da GC pessoal, perguntou-se:

6) Quanto o conhecimento pessoal presente na sua empresa, tem papel preponderante e influenciador do processo de tomada de decisão?

$73 \%$ do total dos entrevistados afirmam que o conhecimento pessoal tem papel preponderante e influenciador no processo decisório, sendo que 47\% afirmam que isso acontece frequentemente, e $27 \%$ afirmaram que ocorre muito frequentemente. Para outros $26 \%$, raramente o conhecimento tácito tem peso significativo para determinar a dinamicidade da tomada de decisão. 
Gráfico 6 - Papel influenciador do conhecimento pessoal na tomada de decisão organizacional

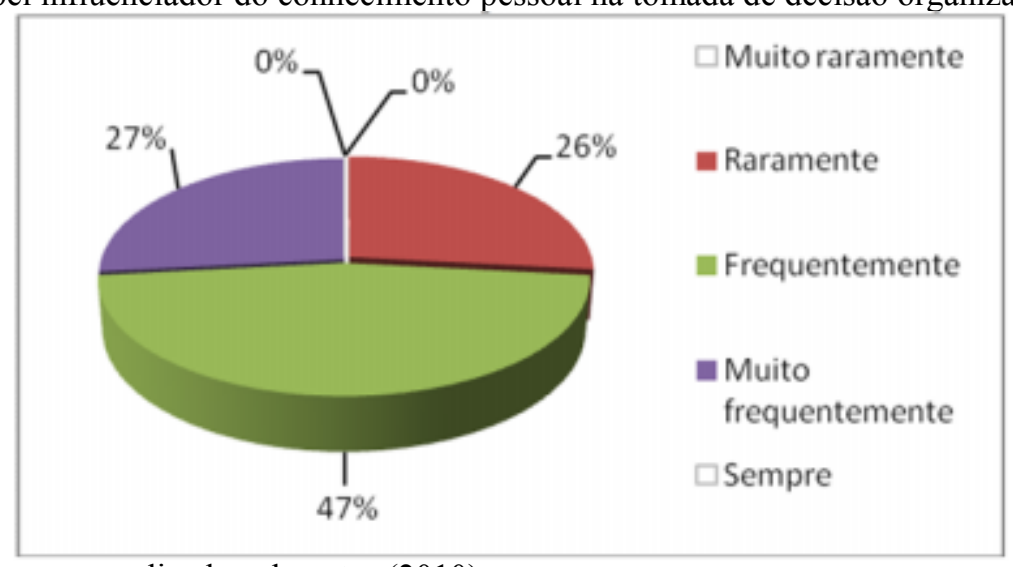

Fonte: Pesquisa de campo realizada pelo autor (2010)

$\mathrm{Na}$ investigação sobre a GC organizacional, buscou-se identificar o grau de sistematização dos procedimentos organizacionais, os quais possam servir de ferramenta de gestão. Para isso foi elaborado o seguinte questionamento:

7) Marque o nível que retrata a existência de um ambiente com normas, regras e premissas escritas (documentadas) em sua empresa, que orientam o executivo no processo de tomada de decisões?

Em 40\% das empresas dos entrevistados, o grau de documentação do conhecimento organizacional existente é regular. Para $27 \%$ dos entrevistados é suficiente. $20 \%$ consideram bom, e $13 \%$ classificam como excelente.

Gráfico 7- Nível de documentação do conhecimento explícito

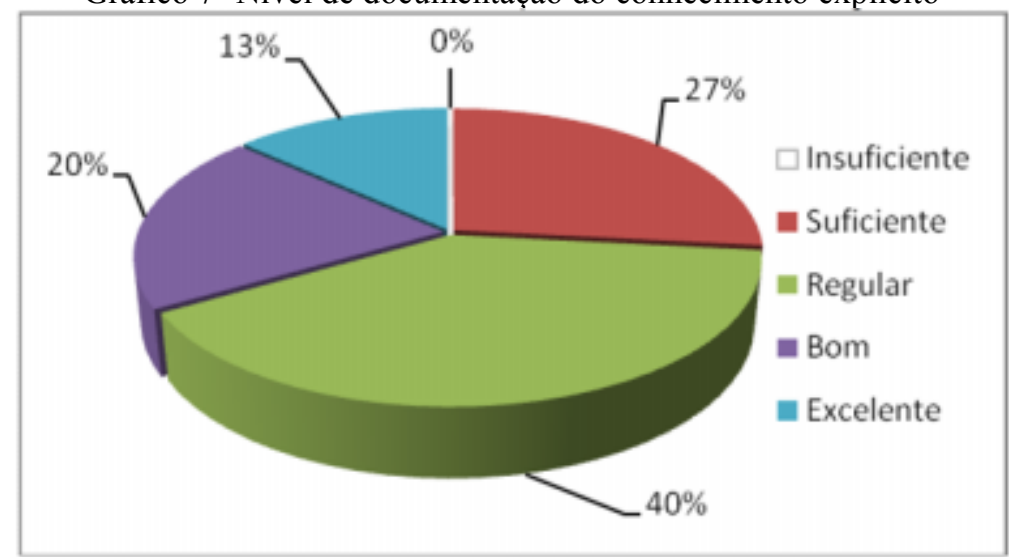

Fonte: Pesquisa de campo realizada pelo autor (2010)

Estes são, portanto, os resultados obtidos, com isso se conclui a apresentação da análise dos dados coletados e se passa à conclusão deste texto.

\section{Conclusões}

Procura-se, então, produzir um tecido composto por reflexões, compreensões, aprendizagens e experiências, onde se entretecerá suposições e proposições ao referencial teórico estrutural deste 
texto, acrescido do resultado obtido na pesquisa aplicada, procurando apontar aquilo que se entende poder ser valioso ou danoso à empresa e ao executivo, no tocante à GC.

O desafio de tomar decisões efetivas e assertivas é grande. Observa-se que, apesar das frequentes e constantes alusões à importância do capital intelectual para uma organização, são poucos os executivos que compreendem a real dimensão de uma empresa criadora de conhecimento, e poucos sabem como administrá-lo, e menos ainda têm consciência do que precisa ser feito para explorá-lo efetivamente.

Admite-se isso, em virtude de incongruências detectadas entre a realidade e os resultados obtidos na pesquisa, onde se constata que a prática da GC, organizacional e pessoal, não acontece de uma maneira expressiva, nem em grau que se faz necessário, muito menos ainda na demanda e na velocidade que o mundo contemporâneo dos negócios impõe. Além disso, observa-se que os executivos não confiam plenamente na qualidade do conhecimento explícito disponível, para fundamentar suas decisões.

Talvez isto ocorra porque eles sabem que, em sua maioria, as empresas não sistematizam o conhecimento corporativo, e, quando isso ocorre, não dão a devida visibilidade a esses documentos, de modo a torná-los acessíveis aos seus funcionários. Essa invisibilidade documental ocasiona uma baixa utilização do ativo intelectual corporativo, obrigando os executivos a lançarem mão, quase que exclusivamente, do seu conhecimento tácito para a tomada de decisões.

Isso, então, sugere que o executivo toma suas decisões de forma solitária, levando em conta apenas o seu conhecimento tácito. Atribui-se isso ao baixo investimento no capital intelectual da empresa, caracterizando que a GC Organizacional e Pessoal não faz parte do foco corporativo. Conclui-se, também, não ser relevante a participação desse capital intelectual no grupo dos influenciadores das estratégias corporativas. Esse papel tem sido exercido mais pelos ditames mercadológicos, do que pela GC Organizacional e Pessoal.

Somente nas empresas de grande porte, e com atuação globalizada, é que se detectou a existência de algum tipo de GC. Provavelmente, devido à necessidade de padronização de procedimentos e à codificação de conhecimento produzido em outras operações da empresa.

O mercado, contudo, é que tem sido a fonte diferencial das informações, utilizada nos processos decisórios. Mas, seria o mercado, realmente, uma fonte segura e adequada para se obter informações para tomar decisões, decisões essas que, por vezes, são determinantes para a sobrevivência da empresa?

E o que se pode dizer da fidedignidade do conhecimento tácito de muitos executivos, que, com frequência, estão mudando de empresa? Seria esse conhecimento tão útil e eficaz ao executivo, nesse novo posto de atuação, a ponto de conduzí-lo a decisões efetivas e assertivas? 
Por um lado pode-se dizer que sim, analisando-se pela ótica de que algumas empresas não costumam fazer GC, e, consequentemente, não o codificam nem criam pontos de apoio ao aprendizado organizacional. Por outro lado, pode-se dizer que não, porque existem diferenças de culturas organizacionais e pessoais, que costumam impactar e afetar o julgamento do executivo, no seu processo decisório, acarretando desvios de gestão, como correções pouco perspicazes de falhas detectadas, confiança exacerbada, inflexibilidade e autoilusão.

Julga-se, então, que, para as pessoas e organizações tomarem decisões de qualidade, faz-se necessário a sistematização clara e precisa do problema, a implementação de um ambiente propício ao desenvolvimento de soluções, a previsão de resultados prováveis e a análise constante das prioridades e da economicidade dos resultados. Decisões dessa natureza, portanto, correm o risco de não serem bem sucedidas. Culturas organizacionais são diferentes, as conjunturas econômicas não são as mesmas, nem a própria avaliação do problema é a mesma, tornando-se arriscado ter como verdadeiro a aplicação de um padrão que norteou uma decisão bem sucedida no passado em outro momento e em outra empresa.

Nessa perspectiva, conclui-se que a GC pessoal não é praticada devidamente, e, consequentemente, o processo decisório dos executivos fica fragilizado, fazendo com que as decisões sejam pouco efetivas e assertivas.

Conclui-se, ainda, ser incipiente o conhecimento, por parte dos executivos, do que vem a ser GC, fato este detectado na tentativa de dissimulação desse desconhecimento.

Espera-se, então, que este material seja útil para aumentar o entendimento de possíveis soluções para questões específicas; que possa servir para ajudar àqueles que vierem a ler este trabalho e que desejam adotar algumas das proposições aqui elaboradas; e, em última análise, que possa ser um instrumento de construção de novos saberes e de novos conhecimentos.

\begin{abstract}
The globalized economy, associated to the Communication and Information Technology, has led to revolutionary changes in social, cultural, economic, demographic and personal concepts and values. This study is an analysis of theoretical contributions, of corporate practices and archetypes of Personal Knowledge Management, based on the management processes of tacit and explicit knowledge. The importance of Personal and Organizational Knowledge Management is the fact that promotes facility in the processes of corporate decision-making, providing better conditions for the executives when they have to deal with information, in order to have reduce ambiguities. As a result the executives will be more able to produce knowledge, to be assertive, and to make effective decisions.
\end{abstract}

Key-words: knowledge management; decision-making process; organizational learning.

\title{
Referências
}

ALLISON, G. T. Essence of decision: explaining Cuban missile crisis. Boston: Little Brown, 1971.

ARIELY, D. O fim da economia racional. Harvard Business Review. v. 87, n. 7, julho 2009.

BAUMAN, Z. Globalização: as consequências humanas. Rio de Janeiro: Jorge Zahar Ed., 1999. 
CANGElOSI, V. E.; DILL, W. R. Organizational learning observations: toward a theory. Administrative Science Quarterly. no 10, p. 175-203, 1965.

creas ret

CHOO, C. W. A organização do conhecimento: como as organizações usam a informação para criar significado, construir conhecimento e tomar decisões. 2. ed. São Paulo: Senac São Paulo, 2006.

COHEN, M. D. et al. A garbage can model of organizational choice. Administrative Science Quartely. v. 17, n. 1, 1972.

CROSSAN, M. M.; LANE, H. W.; WHITE, R. E. An organizational learning framework: from intuition to institution. Academy of Management Review. London: Richard Ivey Scholl of Business, v. 24. n 3, p. 522-537, 1999.

CYERT, R. M.; MARCH, J. G. A behavioral theory of the firm. 2. ed. Oxford: Blackwell, 1992.

DAVENPORT, T.; HARRIS, J. G. Competição analítica vencendo através da nova ciência: como decisões baseadas em fatos e business intelligence transformaram os negócios. Rio de Janeiro: Elsevier, 2007.

, PRUSAK, L. Conhecimento empresarial. Rio de Janeiro: Campus: São Paulo: Publifolha, 1999.

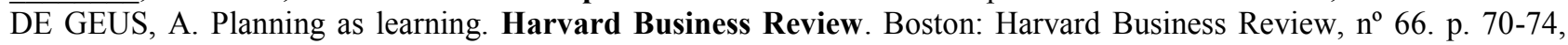
1988.

. The living company. Boston: Harvard Business School Press, 1997.

DRUCKER, P. Beyond the information revolution. Atlantic Monthly, v. 284, n. 4; 47-57, 1999.

Sociedade pós-capitalista. São Paulo: Pioneira; São Paulo: Publifolha, 1999.

DUNCAN, R. B. The characteristics of organizational environments and perceived environmental uncertainty.

Administrative Science Quarterly, v. 17, n. 320, 1972.

FERREIRA, A. B. H. Novo dicionário Aurélio da língua portuguesa. 3. ed. Curitiba: Positivo, 2009.

FLEURY, M. T. L.; OLIVEIRA J.; Moacir, M. Gestão estratégica do conhecimento: integrando aprendizagem, conhecimento e competências. 1. ed. 5. reimpr. São Paulo: Atlas, 2008.

GLADWELL, M. B. A decisão num piscar de olhos. Rio de Janeiro: Rocco, 2005.

JOHNSON-LAIRD, P. N. Mental models: toward a cognitive science of language, inference and consciousness.

Cambridge: Cambridge University Press, 1983.

KLEIN, G. Fontes do poder: o modo como as pessoas tomam decisões. Boston: Massachusetts Institute of Technology: Lisboa: Instituto Piaget, 1998.

LAKATOS, E. M.; MARCONI, M. A. Fundamentos de metodologia científica. 6. ed., São Paulo: Ed. Atlas, 2008.

LASTRES, H. M. M.; ALBAGLI, S. Informação e globalização na era do conhecimento. Rio de Janeiro: Campus, 1999.

LEHRER, J. How we decide. New York: Houghton Mifflin Harcourt, 2009.

MARCH, J. G. Exploration and exploitation in organizational learning. Organization Science, nº 2. p. 71- 87, 1991.
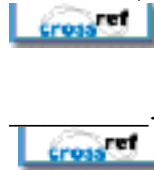

How decisions happen in organizations. Stanford: Human-Computer Interaction, v. 6, p. 95-117, 1991.

MARCH, J. G.; OLSEN, J. P. Organizational learning under ambiguity. European Journal of Policy Review, v. 3. $n^{\circ}$ 2. p. $147-171,1975$.

MARCH, J. G.; SIMON, H. A. Organizations. 2. ed. Oxford: Blackwell, 1993.

. The pursuit of organizational intelligence: decisions and learning in organizations. Cambridge: Blackwell

Publishers, 1999 
MENDES, S. P. Gestão do conhecimento individual - a physis, o homem, o conhecimento e a gestão: uma abordagem filosófica. Florianópolis: VisualBooks, 2005.

MINTZBERG, H.; AHLSTRAND, B.; LAMPEL, J. Safári da estratégia: um roteiro pela selva do planejamento estratégico. reimp., Porto Alegre: Bookman, 2007.

Criando organizações eficazes: estruturas em cinco configurações. 2. ed., São Paulo: Atlas, 2008.

1976.

et al. The structure of "unstructured" decision processes. Administrative Science Quarterly. v. 21 . n. 2.

NONAKA, I.; TAKEUCHI, H. Criação de conhecimento na empresa: como as empresas japonesas geram a dinâmica da inovação. 19. reimpr. Rio de Janeiro: Elsevier, 1997.

Gestão do conhecimento. Porto Alegre: Bookman, 2008.

ORGANISATION FOR ECONOMIC CO-OPERATION AND DEVELOPMENT - OCDE. The knowledge-based economy. Paris: OCDE, 1996. Disponível em: http://www.oecd.org/dataoecd/51/8/1913021.pdf. Acessado em 26 Dez. 2009.

PEREZ, C. Technological revolutions and financial capital: the dynamics of bubbles and golden ages. reimp., Cheltenham, UK: Edward Elgar, 2005.

POLANYI, M. Knowing and being. Mind, New Series, Oxford University Press: Mind Association, v. 70, n. 280, 458-470, 1961.

The Tacit Dimension. Chicago: University of Chicago Press edition, 2009.

PROBST, G.; RAUB, S.; ROMHARDT, K. Gestão do conhecimento: os elementos construtivos do sucesso. Porto Alegre: Bookman, 2002.

REZENDE, D. A. Alinhamento do planejamento estratégico da informação ao planejamento empresarial: proposta de um modelo e verificação da prática em grandes empresas brasileiras. Florianópolis, 2002, Tese (Doutorado em Gestão da Tecnologia da Informação). Programa de Pós-graduação em Engenharia de Produção, Universidade Federal de Santa Catarina.

RUSSEL, B. Fundamentos de filosofia. Rio de Janeiro: Zahar, 1977.

SCHUMPETER, J. A. Teoria do desenvolvimento econômico: uma investigação sobre lucros, capital, crédito, juro e o ciclo econômico. 2. ed. São Paulo: Nova Fronteira, 1985.

SENGE, P. M. A quinta disciplina: arte e prática da organização que aprende. 24. ed. Rio de Janeiro: BestSeller, 2008.

SIMON, H. A. Comportamento administrativo: estudo dos processos decisórios nas organizações administrativas. 2. ed. rev. Rio de Janeiro: FGV, 1970.

Models of man: social and rational. Nova York: John Wiley, 1957.

STIGLITZ, J. Globalization and its discontents. London: Penguin Uk, 2003.

SVEIBY, K. E. The new organizational wealth: managing and measuring knowledge-based assets. San Francisco: Berrett-Koehler Publishers, 1997.

WEICK, K. E. A psicologia social da organização. São Paulo: USP, 1973.

\section{Dados dos autores:}

Nome completo: Gilberto dos Santos Madeira

Filiação institucional: Fundação Getúlio Vargas - FGV 
Departamento: FGV Mangement - Cademp

Função ou cargo ocupado: Professor-convidado

Endereço completo para correspondência (bairro, cidade, estado, país e CEP): Rua Luís Ruzalém, 226 - Condomínio Terras de Vinhedo - Vinhedo - SP - Brasil - 13280-000

Telefones para contato: (19) 3876-0257, (19) 8123-1640 e (19) 9204-3443

e-mail:gilmadeira@fgvmail.br ; gilmadeira@uol.com.br

Nome completo: Moacir Pereira

Filiação institucional: Fundação Getúlio Vargas - FGV

Departamento: Cademp

Função ou cargo ocupado: Professor-convidado

Endereço completo para correspondência (bairro, cidade, estado, país e CEP): Rua Exp. Hélio Alves Camargo, 52 - Jd. Chapadão - 13.070-193 - Campinas/SP

Telefones para contato: (19) 3213-1797 e (19) 9779-8911

e-mail: pereiramoacir@yahoo.com.br

Recebido para publicação em: 22/09/2010

Aceito para publicação em: 25/11/2010 